\title{
Metabotropic Glutamate Receptors: Potential Drug Targets for Psychiatric Disorders
}

\author{
Akito Yasuhara*,a and Shigeyuki Chaki ${ }^{\mathrm{b}}$ \\ ${ }^{a}$ Medicinal Chemistry Laboratories, Taisho Pharmaceutical Co., Ltd; ${ }^{b}$ Molecular Function and Pharmacology, Taisho
Pharmaceutical Co., Ltd. Yoshino-cho, 1-403, kita-ku, Satitama 331-9530, Japan
}

\begin{abstract}
Metabotropic glutamate receptors (mGlu receptors) have emerged as new therapeutic targets for psychiatric disorders, such as schizophrenia, depression and anxiety with their regulatory roles in glutamatergic transmissions. To date, several ligands selective for each mGlu receptor have been synthesized, and pharmacological significances of these ligands have been demonstrated in animal models. Among them, mGlu2/3 receptor agonists have been proven to be effective for treating schizophrenia and anxiety disorders in clinical studies, which may prove utilities of mGlu receptor ligands for the treatment of psychiatric disorders. This article reviews recent advances in development of each mGlu receptor ligands and their therapeutic potential.
\end{abstract}

Keywords: Metabotropic glutamate receptor, mGlu, psychiatric disorder, drug target.

\section{INTRODUCTION}

Glutamate is the major excitatory neurotransmitter in the brain. It is involved in a wide range of physiological processes in the central nervous system that are associated with emotion, cognition and motor functions. Glutamate receptors are categorized into 2 major types: ionotropic glutamate receptors (iGlu receptors), in which the receptors have an ion channel structure; and metabotropic glutamate receptors (mGlu receptors), which are coupled to G-proteins $[1,2]$. iGlu receptors, which facilitate fast synaptic transmission, are also classified into $N$-methyl-D-aspartate (NMDA), $\alpha$-amino-3-hydroxy-5-methyl-isoxazole-4-propionate (AMPA) and kainate receptors $[1,2]$. mGlu receptors also have several isoforms (mGlu1-mGlu8).

mGlu receptors are currently classified into 3 groups based on their sequence homology, second messenger coupling, and pharmacological characteristics (Table 1) [3-5]. Group I mGlu receptors include mGlu1 and mGlu5 that are coupled to phospholipase C, while both group II mGlu receptors (mGlu2 and mGlu3) and group III mGlu receptors (mGlu4, mGlu6, mGlu7, and mGlu8) are negatively coupled to adenylyl cyclase activity. Among these mGlu receptors, numerous ligands (agonists, antagonists, positive modulators or negative modulators) have been developed for the mGlu2/3 and mGlu5 receptors. Studies using these ligands have been established their physiological and pharmaco-logical significance as well as their possible therapeutic applications.

A growing body of evidence shows that manipulations of the mGlu2/3 and mGlu5 receptors exhibit significant pharma-

\footnotetext{
*Address correspondence to this author at the Medicinal Chemistry Laboratories, Taisho Pharmaceutical Co., Ltd. Yoshino-cho, 1-403, kita-ku, Satitama 331-9530, Japan; Tel: +81-48-669-3029; Fax: +81-48-652-7254; E-mail: a.yasuhara@po.rd.taisho.co.jp
}

cological effects in numerous animal models, including models for psychiatric disorders. In addition, mGlu2/3 receptor agonists have demonstrated efficacy in clinical studies in patients with schizophrenia [6] or anxiety disorders [7-9]. This review will focus on recent developments of agonists/antagonists, including allosteric modulators for mGlu receptors and the possible therapeutic application of these ligands for the treatment of psychiatric disorders, such as schizophrenia and depression.

\section{SCHIZOPHRENIA}

\subsection{Role of Glutamatergic Transmission in Schizophrenia}

In addition to the well-established "dopamine hypothesis of schizophrenia," it has also been suggested that abnormalities of glutamate transmission are involved in the pathophysiology of schizophrenia. Significantly lower levels of glutamate are found in the cerebrospinal fluid (CSF) and in postmortem brain tissues of schizophrenic patients [10, 11]. CSF glutamate levels are also inversely correlated with the severity of positive symptoms in unmedicated patients [12]. Phencyclidine (PCP) and ketamine, non-competitive NMDA receptor antagonists, produce transient psychoses, disrupted affect and caused cognitive impairments in healthy volunteers, all of which are similar to what are observed in schizophrenia [13-16], and lead to profound exacerbations of pre-existing symptoms in schizophrenic patients [15]. Moreover, NMDA receptor antagonists and transgenic manipulation of an NMDA receptor subunit (NR1) induce schizophrenia-like behavioral abnormalities (increased locomotor activity, reduced social interaction, cognitive dysfunction), which are ameliorated by antipsychotic treatments [1719].

Thus, glutamatergic dysfunction, and hypofunction of NMDA receptors in particular, may have an important role in the pathophysiology of schizophrenia. Because mGlu 
Table 1. Classification and Characteristics of mGlu Receptors

\begin{tabular}{|c|c|c|c|c|c|c|c|c|}
\hline & \multicolumn{2}{|c|}{ Group I } & \multicolumn{2}{|c|}{ Group II } & \multicolumn{4}{|c|}{ Group III } \\
\hline & mGlu1 & mGlu5 & mGlu2 & mGlu3 & mGlu4 & mGlu6 & mGlu7 & mGlu8 \\
\hline Signaling & \multicolumn{2}{|c|}{$\begin{array}{c}\mathrm{Gq} / 11 \\
\text { Activation of phospholipase C }\end{array}$} & \multicolumn{2}{|c|}{$\begin{array}{c}\mathrm{Gi} / \mathrm{o} \\
\text { Inhibition of adenylyl cyclase }\end{array}$} & \multicolumn{4}{|c|}{$\begin{array}{c}\mathrm{Gi} / \mathrm{o} \\
\text { Inhibition of adenylyl cyclase }\end{array}$} \\
\hline Agonists & DHPG & CHPG & $\begin{array}{l}\text { LY404039, } \\
\text { LY354740, } \\
\text { MGS0028, } \\
\text { MGS0008 }\end{array}$ & $\begin{array}{l}\text { LY404039, } \\
\text { LY354740, } \\
\text { MGS0028, } \\
\text { MGS0008 }\end{array}$ & $\begin{array}{l}\text { L-AP4, } \\
\text { PHCCC }\end{array}$ & HomoAMPA & $\begin{array}{l}\text { L-AP4, } \\
\text { AMN082 }\end{array}$ & $\begin{array}{l}\text { L-AP4, } \\
\text { RS-PPG }\end{array}$ \\
\hline $\begin{array}{c}\text { Positive } \\
\text { allosteric } \\
\text { modulators }\end{array}$ & & $\begin{array}{c}\text { DFB, CDPPB, } \\
\text { CPPHA, } \\
\text { ADX47273 }\end{array}$ & $\begin{array}{l}\text { LY487379, } \\
\text { BINA }\end{array}$ & & & & AMN082 & \\
\hline Antagonists & $\begin{array}{l}\text { JNJ16567083, } \\
\text { LY367385 }\end{array}$ & MPEP, MTEP & $\begin{array}{l}\text { LY341495, } \\
\text { MGS0039 }\end{array}$ & $\begin{array}{l}\text { LY341495, } \\
\text { MGS0039 }\end{array}$ & CPPG & CPPG & CPPG & CPPG \\
\hline
\end{tabular}

receptors have modulatory roles on NMDA receptormediated transmission, mGlu receptor ligands may be attractive therapeutic targets for the treatment of schizophrenia.

\section{2. mGlu2/3 Receptor Agonists/mGlu2 Receptor Potentiators}

In recent years, several lines of evidence have shown that mGlu2/3 receptor agonists may be effective for the treatment of schizophrenia in both animal models and in humans. mGlu2/3 receptor agonists, such as $(1 S, 2 S, 5 R, 6 S)-2-$ aminobicyclo[3.1.0]hexane-2,6-dicarboxylic acid (LY3547 40), have been reported to attenuate locomotor hyperactivity induced by an NMDA receptor antagonist in rodents [20]. Similar effects were observed with other mGlu2/3 receptor agonists, including (-)-(1R,4S,5S,6S)-4-amino-2-sulfonylbicyclo[3.1.0]hexane-4,6-dicarboxylic acid (LY404039) [21], (1S,2R,5R,6R)-2-amino-4-oxabicyclo[3.1.0]hexane-2,6dicarboxylic acid (LY379268) [22], (1S,2S,3S,5R,6S)-2amino-3-fluorobicyclo[3.1.0]hexane-2,6-dicarboxylic acid (MGS0008), and (1R,2S,5S,6S)-2-amino-6-fluoro-4-oxobicyclo[3.1.0]hexane-2,6-dicarboxylic acid (MGS0028) [23]. Moreover, mGlu2/3 receptor agonists have been shown to inhibit amphetamine-induced locomotor hyperactivity [21, 24] and conditioned avoidance responding [21, 25]. These models may be predictive of the efficacy for positive symptoms of schizophrenia. Therefore, mGlu2/3 receptor agonists may be effective for the treatment of positive symptoms of schizophrenia.

The effect of LY404039 on PCP- or amphetamineinduced locomotor hyperactivity is absent in mGlu2 receptor- or mGlu $2 / 3$ receptor-null mice, but not in mGlu3 receptor-null mice [26]. In addition, the effects of mGlu2/3 receptor agonists on PCP- or amphetamine-induced locomotor hyperactivity were mimicked by the selective mGlu2 receptor potentiator $N$-(4-(2-methoxyphenoxy)phenyl)- $N$-(2,2,2-trifluoroethylsulfonyl)pyrid-3-ylmethylamine (LY487379) [24]. Thus, the mGlu2 receptor, but not the mGlu3 receptor, is responsible for the antipsychotic actions of $m G l u 2 / 3$ receptor agonists.

LY354740 improved PCP-impaired performance in a Tmaze discrete-trial delayed alternation task [20] and reversed the deficits of social discrimination induced by neonatal treatment with PCP [27]. These findings suggested the potential of mGlu2/3 receptor agonists to improve the cognitive dysfunctions observed in schizophrenic patients. However, there are some contradictory findings indicating that $\mathrm{mGlu} 2 / 3$ receptor agonists may not improve cognitive dysfunction, and may even cause it to deteriorate.

For example, LY354740 induced working memory deficits in delayed matching and non-matching to position and spatial memory tasks in a Morris water maze [28], and did not improve PCP-induced cognitive deficits in a spontaneous alternation task and passive avoidance task [29]. Moreover, mGlu2/3 receptor agonists did not reverse amphetamine- or PCP-induced disruption of prepulse inhibition (PPI) [24, 30], a fundamental form of information processing that is impaired in schizophrenic patients.

In contrast, a selective mGlu2 receptor potentiator, LY487379, significantly improved amphetamine-disrupted PPI [24], and also significantly improved social discrimination deficits induced after neonatal treatment with PCP [28]. Based on these findings, the effects of mGlu2/3 receptor agonists may be task-dependent or influenced by the conditions that were used. It is also conceivable that selective mGlu2 receptor stimulation may be important in order to fully exert its effects on cognitive dysfunction, while mGlu3 receptor stimulation may have opposite effects.

The neuronal mechanisms by which $\mathrm{mGlu} 2 / 3$ receptor agonists exert their effects have been investigated. mGlu2/3 receptor agonists are considered to exert their effects by acting on the glutamatergic, dopaminergic, and 5-HTergic pathways. Administration of NMDA receptor antagonists increases glutamate release in the prefrontal cortex, and also elicits working memory dysfunction [20, 31, 32]. Thus, it is presumed that NMDA receptor dysfunction in the prefrontal cortex increases glutamate release and, thereby, impairs working memory.

mGlu2/3 receptor agonists have been shown to attenuate the increased glutamate release caused by blockade of NMDA receptors. Consistent with this result, a marked increase in relative cerebral blood volume, which reflects hypermetabolism associated with increased glutamate release, was seen in the prefrontal cortex in rats following 
administration of PCP, as determined by pharmacological magnetic resonance imaging. LY354740 attenuated this metabolic hyperactivity [33]. Given that prefrontal abnormallities are assumed to be involved in the etiology of schizophrenic symptoms, attenuation of prefrontal abnormalllities (glutamate overflow and hypermetabolism) may contribute to the antipsychotic actions of $\mathrm{mGlu} 2 / 3$ receptor agonists.

Moreover, an mGlu2/3 receptor agonist inhibited PCPincreased dopamine flow in the nucleus accumbens shell [34], while it increased dopamine release in the prefrontal cortex [21, 35]. Given that accumbal dopaminergic hyperactivity is associated with positive symptoms of schizophrenia, while prefrontal dopaminergic hypoactivity is associated with impairment of cognition, these differential effects of mGlu2/3 receptor agonists could contribute to the antipsychotic effects of $\mathrm{mGlu} 2 / 3$ receptor agonists.

Recently, interactions between the 5-HT2A and mGlu2 receptors have been suggested. LY354740 attenuated serotonin-induced excitatory postsynaptic currents recorded in layer $\mathrm{V}$ pyramidal cells of the medial prefrontal cortex, suggesting that mGlu2/3 receptors negatively regulated 5HT2A receptor-mediated responses to stimulate glutamate release, presumably from thalamocortical afferents to the prefrontal cortex. Moreover, LY354740 attenuated 5-HT2A receptor agonist-induced head shakes in rats [36]. Attenuation of 5-HT2A receptor-mediated electrophysiological and behavioral responses was mimicked by an mGlu 2 receptor potentiator [37], indicating that the mGlu2 receptor, but not the mGlu3 receptor, was involved in this event. It was also recently shown that the 5-HT2A and mGlu2 receptors formed a heterodimeric complex [38]. Thus, it is intriguing to assume that the mGlu2 receptor may exert its effects, in part, by inhibiting 5-HT2A receptor signaling via the mGlu2 receptor-5-HT2A receptor complex.

The efficacy of an mGlu2/3 receptor agonist, LY2140023 (a methionine amide of LY404039), was reported in a randomized, double-blinded, placebo-controlled study of 196 schizophrenic patients [6]. LY2140023 significantly improved both positive and negative symptoms, as observed with olanzapine. LY2140023 neither increased prolactine nor worsened extrapyramidal symptoms. Furthermore, LY2140 023 did not affect body weight unlike olanzapine, which causes increased body weight. Therefore, mGlu2/3 receptor agonists may be effective and safe as monotherapy for the treatment of schizophrenia, although larger and longer-term studies are needed to verify this.

\section{3. mGlu5 Receptor Agonists/mGlu5 Receptor Potentiators}

$(R S)$-2-Chloro-5-hydroxyphenylglycine (CHPG), an mGlu5 receptor agonist, has been reported to attenuate ketamine-induced increases in locomotor hyperactivity, and to improve PPI disruption and object recognition memory impairment induced by ketamine [39]. Similarly, CHPG ameliorated PPI disruption induced by amphetamine [40], indicating that mGlu5 receptor stimulation exerts antipsychotic activity in animal models. mGlu5 receptor potentiators offer an attractive alternative to the direct mGlu5 receptor activation by orthosteric competitive agonists.
To date, several structurally diverse mGlu5 receptor potentiators have been reported, including 3,3'-difluorobenaldazine (DFB), $S$-(4-fluoro-phenyl)-\{3-[3-(4-fluoro-phenyl)-[1,2,4]oxadiazol-5-yl]-piperidin-1-yl $\}$-methanone (ADX47273) and 3-cyano- $N$-(1,3-diphenyl-1H-pyrazol-5yl)benzamide (CDPPB). These compounds reportedly prevented locomotor hyperactivity induced by PCP, ketamine, amphetamine, and apomorphine [39, 41, 42]. ADX47273 also reduced conditioned avoidance responding in rats [42]. These findings suggest that mGlu5 receptor potentiation may be effective for the positive symptoms of schizophrenia.

The efficacy of mGlu5 receptor potentiators for cognitive dysfunctions has also been reported. CDPPB improved PPI disruption induced by amphetamine [41]. In a novel object recognition test, $\mathrm{CDPPB}$ or DFB improved the impaired recognition capability that was induced by MK-801 or ketamine [42, 43]. CDPPB also attenuated MK-801-impaired task performance in a set-shifting paradigm [44]. Therefore, enhancement of mGlu5 receptor activity with mGlu5 receptor potentiators may be effective for treating the dysfunctions of several cognitive domains associated with schizophrenia.

In addition to improving cognitive deficits, mGlu5 receptor potentiators, including $\mathrm{ADX} 47273, \mathrm{DFB}$, and CDPPB, also enhanced object recognition memory in a novel object recognition test [42] and spatial memory in $\mathrm{Y}$ maze spatial alternation [45] and Morris water maze tasks [46], indicating that mGlu5 receptor potentiators may have memory-enhancing effects, even for normal conditions. The involvement of the mGlu5 receptor on cognition is supported by a study of mGlu5 receptor-null mice. These mice exhibited reduced long-term potentiation in the CA1 region and dentate gyrus of the hippocampus (NMDA receptordependent pathways), but not in the CA3 region (an NMDA receptor-independent pathway). mGlu5 receptor-null mice also displayed impaired spatial learning in a Morris water maze task, impaired contextual learning during fear-conditioning [47] and disrupted PPI [40].

The neuronal mechanisms by which mGlu5 receptor potentiation exerts antipsychotic and cognitive enhancing effects have been considered in relation to stimulation of NMDA receptor function. The mGlu5 receptor positively regulates NMDA receptor function. mGlu5 receptor agonists potentiated NMDA receptor function in multiple neuron populations [48, 49], and this was not observed in knockout mice lacking mGlu5 receptors. Similarly, an mGlu5 receptor potentiator, $\mathrm{N}$-\{4-chloro-2-[(1,3-dioxo-1,3-dihydro- $\mathrm{H}$-isoindol-2-yl)methyl]phenyl\}-2-hydroxybenzamide (CPPHA), potentiated NMDA currents in hippocampal slices induced by a threshold level of DHPG [50]. In addition, an mGlu5 receptor potentiator, $\mathrm{CDPPB}$, prevented MK-801-induced excessive firing and reduced spontaneous bursting in the medial prefrontal cortex [51]. These findings indicate that mGlu5 receptor stimulation may ameliorate abnormalities in prefrontal cortical neuronal activity, which may be responsible for frontal cortex dependent cognitive function.

Conversely, mGlu5 receptor antagonists potentiated the spontaneous burst and spike activity of cortical neurons [52] and psychotomimetic effects, both of which were induced by NMDA receptor antagonists [49]. Interactions between the mGlu5 and NMDA receptors at the molecular level have 
been indicated by reports showing that an mGlu5 receptor agonist, DHPG, increased phosphorylation of NMDA NR1 at Ser-897 (a substrate for protein kinase C) in brain slices [53], and that administration of DHPG also increased phosphorylation of NR1 at Ser-897 [54]. Because decreased Ser-897 on the NR1 receptor has been reported in the brains of schizophrenic patients, and antipsychotic drugs increased Ser-897 on NR1 [55, 56], an increase of Ser-897 phosphorylation on NR1 by mGlu5 receptor stimulation is of interest in light of the mGlu5 receptor involvement in schizophrenia.

\section{4. mGlu1 Receptor Antagonists}

mGlu1 receptor antagonists such as [4-[1-(2-fluoropyridine-3-yl)-5-methyl-1 $H$-1,2,3-triazol-4-yl]- $N$-isopropyl- $N$-methyl-3,6-dihydropyridine-1(2H)-carboxamide] (FTIDC) and 2-cyclopropyl-5-[1-(2-fluoro-3-pyridinyl)-5-methyl-1 $H$ -

1,2,3-triazol-4-yl]-2,3-dihydro- $1 H$-isoindol-1-one (CFMTI) have been reported to exhibit antipsychotic effects in rodent models of schizophrenia. Of note, these mGlu1 receptor antagonists reduced maximal responses of L-glutamate [57, 58], suggesting that both compounds acted as noncompetitive antagonists for the mGlu1 receptor. Thus, FITDC antagonized methamphetamine-induced locomotor hyperactivity and methamphetamine-disrupted PPI [59].

Antipsychotic-like potentials of mGlu1 receptor antagonists have been further characterized by studies using a potent and selective mGlu1 receptor antagonist CFMTI [58]. As observed with FTIDC, at the doses which antagonizes mGlu1 receptor-mediated behavior (facewashing behavior), CFMTI reduced methamphetamineinduced locomotor hyperactivity and disruption of PPI without affecting spontaneous locomotor activity. Moreover, CFMTI attenuated locomotor hyperactivity and PPI disruption induced by ketamine, and reversed MK-801reduced social interaction (regarded as social withdrawal, one of the negative symptoms). Therefore, based on animal studies, mGlu1 receptor antagonists may have efficacy for positive and negative symptoms, and a certain domain of cognitive dysfunction of schizophrenia.

In contrast, mGlu1 receptor antagonists neither induced catalepsy nor impaired rotarod performance [58, 59], suggesting that mGlu1 receptor antagonists may not cause motor dysfunction, unlike the actions of typical antipsychotics. This atypical activity of mGlu1 receptor antagonists is further supported by c-fos induction, in that CFTI induces c-fos in the medial prefrontal cortex and nucleus accumbens, but not in the dorsolateral striatum, which is in line with the results using clozapine [58].

The neurochemical mechanisms underlying the antipsychotic actions of mGlu1 receptor antagonists are not fully understood. Injection of DHPG, a group I mGlu receptor agonist, into the medial prefrontal cortex increased glutamate release, and an mGlu1 receptor antagonist blocked this [60]. Thus, regulation of glutamate overflow in the medial prefrontal cortex by mGlu1 receptor blockade may be responsible for the pharmacological actions of mGlu1 receptor antagonists.

\section{MOOD DISORDERS}

\section{1. Role of Glutamatergic Transmission in Depression}

Emerging evidence suggests that abnormalities of glutamatergic systems are involved in depression, although the extent and direction of these changes remain subjects of debate. Blood glutamate levels have been shown to increase in medicated patients [61, 62]. Mitani et al. [63] reported that increased glutamate plasma levels reflected the severity of depression. Sanacora et al. [64] reported significantly increased glutamate levels in the occipital cortex in depressed patients as compared to healthy controls.

In contrast, glutamate levels in the anterior cingulate cortex and frontal cortex of patients with major depression were reduced $[65,66]$, while total REM sleep suppression, an efficient method for relieving depression, produced robust increases in glutamate levels in the pons [67]. Pfleiderer et al. [68] reported reduced Glx (glutamate/glutamine) levels in the left anterior cingulate cortex in severely depressed unipolar patients, which were normalized by electroconvulsive therapy. Abnormalities in expression levels of the NMDA receptor and glial type glutamate transporters (EAAT1 and EAAT2) have been reported in postmortem studies of human suicide victims and major depression $[69$, 70].

In addition, ketamine (an NMDA receptor antagonist) and riluzole (a glutamate modulator) exerted antidepressant activities in patients with major depressive disorders who were unresponsive to conventional antidepressants [71 -73]. In particular, ketamine reportedly exerted a rapid, sustained and robust antidepressant effect. Thus, modulation of glutamatergic transmission might be an effective approach to treating patients with depression, in particular patients with treatment-resistant depression.

\section{2. mGlu2/3 Receptor Antagonists}

Recently, the mGlu2/3 receptor was shown to be involved in depression using selective mGlu2/3 receptor antagonists in rodent models. mGlu $2 / 3$ receptor antagonists, MGS0039 and LY341495, shortened immobility times in 2 behavioral despair models, a rat forced swim test, and a mouse tail suspension test [74]. Similar antidepressant effects of an mGlu2/3 receptor antagonist in a despair model were confirmed by Witkin et al. [75]. An antidepressant-like phenotype (reduced immobility time) in a forced swim test was observed in knockout mice lacking mGlu2 receptors [76], suggesting that the mGlu2 receptor may be involved in the antidepressant effects of mGlu2/3 receptor antagonists. In addition, LY341495 attenuated the threshold elevations observed in rats undergoing spontaneous nicotine withdrawal [77]. The threshold elevation following withdrawal from chronic treatment with drugs of abuse has been proposed to reflect anhedonia (loss of interest or pleasure), which is a core symptom of depression [78], and provides additional evidence that mGlu2/3 receptor antagonists may have antidepressant effects. Moreover, subchronic administration of MGS0039 reduced escape failures in a learned helplessness paradigm, indicating antidepressant activity [79].

Neuronal mechanisms underlying the antidepressant effects of mGlu2/3 receptor antagonists have also been 
investigated. For example, MGS0039 increased the firing rate of the dorsal raphe nucleus and increased serotonin release in the medial prefrontal cortex [80]. This was consistent with the behavioral profile in the forced swim test that showed that mGlu $2 / 3$ receptor antagonists selectively increased swimming behavior, as did SSRIs. In addition to serotonergic transmission, MGS0039 increased dopamine release in the nucleus accumbens shell [81], which may explain the anti-anhedonic effect of mGlu2/3 receptor antagonists, as dopaminergic activity in the nucleus accumbens is closely related to reward activity. Also, subchronic administration of MGS0039 increased hippocampal neurogenesis [82], which has been shown to be one mechanism for the actions of antidepressants.

Interestingly, some of the actions of MGS0039 were attenuated by an AMPA receptor antagonist, NBQX [83, 84], suggesting that MGS0039 exerts its effects through AMPA receptor activation. Given that AMPA receptor potentiators have been shown to exhibit antidepressant effects in animal models [85], and that AMPA receptor activation has been suggested to be involved in the antidepressant actions of ketamine and riluzole [86, 87], which are effective antidepressant treatments, this mechanism is of interest in terms of the efficacy of mGlu2/3 receptor antagonists for the treating depression in the clinic.

\section{3. mGlu5 Receptor Antagonists}

The antidepressant potentials of mGlu5 receptor antagonists have been investigated using selective allosteric negative modulators, such as 6-methyl-2-(phenylethynyl)pyridine (MPEP) and 3-[(2-methyl-1,3-thiazol-4-yl)ethynyl]pyridine (MTEP). Both compounds reduced immobility times in despair models, such as forced swim and tail suspension tests [88-90]. The antidepressant effects of MPEP in the forced swim test were no longer observed in knockout mice lacking mGlu5 receptors [88], indicating that these compounds exerted their effects via the mGlu5 receptor. Moreover, subchronic administration of MPEP or MTEP attenuated abnormal behaviors (learning deficits in a passive avoidance paradigm or locomotor hyperactivity in a novel environment) induced by olfactory bulbectomy [89, 91]. Molina-Hernandez et al. [92] reported that MTEP injection into the lateral septal nuclei increased reinforced lever presses and caused a comprehensive rightward shift of the inter-response time, as observed with desipramine in the differential-reinforcement-of-low-rate 72-s paradigm, thus providing additional evidence for mGlu5 receptor antagonists for antidepressant treatment.

The neuronal mechanisms underlying the antidepressant effects of mGlu5 receptor antagonists have not been fully elucidated. Interactions between the mGlu5 and NMDA receptors have been proposed to be involved in the actions of mGlu5 receptor antagonists. As described in [2.3], the mGlu5 receptor positively regulated NMDA receptor function. Thus, mGlu5 receptor blockade may have a negative impact on NMDA receptor function. This is interesting, as NMDA receptor antagonists like ketamine have been proven to be a very effective approach for treating depression in both animal models and clinical studies [71, 72, 87]. Moreover, mGlu5 receptor activation on astrocytes increases glutamate release from glial cells in the nucleus accumbens, and glutamate released from glial cells selectively activates extrasynaptic NR2B-containing NMDA receptors, but not intrasynaptic NR2A-containing NMDA receptors [93]. Because increased glutamate release from glial cells, which leads to stimulation of extrasynaptic NMDA receptors, has been considered to be among the causes of depression, indirect extrasynaptic NMDA receptor blockade by mGlu5 receptor antagonists could be a very interesting approach to treating depression.

\section{4. mGlu7 Receptor Ligands}

Roles for the mGlu7 receptor in depression have been studied, although its involvement is rather complicated. Knockout mice lacking mGlu7 receptors displayed antidepressant-like phenotypes in a forced swim test and a tail suspension test without significant changes in locomotor activities [94]. mRNA expression levels of the glucocorticoid and 5-HT1A receptors in the hippocampus increased in mGlu7 receptor-null mice [95], suggesting that a feedback mechanism within the HPA axis may be enhanced. In line with this observation, mGlu7 receptor-null mice showed hypersensitivity to dexamethasone, as demonstrated by a marked serum corticosterone reduction in response to dexamethasone challenge [95]. This is opposite to what is seen in many depressed patients who have a blunted response to dexamethasone challenge [96].

In contrast, $\mathrm{N}, \mathrm{N}$-dibenzhydrylethane-1,2-diamine dihydrochloride (AMN082), an allosteric mGlu7 receptor agonist, exhibited antidepressant effects in forced swim and tail suspension tests [97]. The antidepressant effect of AMN082 was not observed in knockout mice lacking mGlu7 receptors, showing that AMN082 exerted its effect through mGlu7 receptor activation. Contradictory findings between stimulation and blockade of this receptor remain to be resolved.

Although not statistically significant, results with mGlu7 receptor-null mice showed increased locomotor activity, which may affect the outcomes in the forced swim test. In addition, the mGlu7 receptor undergoes rapid internalization

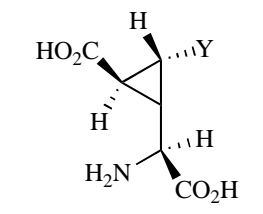

$\mathrm{X}=\mathrm{H}: \mathrm{L}-\mathrm{CCD}-\mathrm{I}$

$\mathrm{X}=\mathrm{CO}_{2} \mathrm{H}$ : DCG-IV

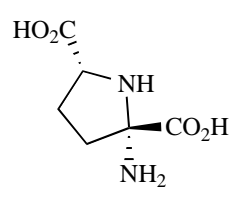

APDC

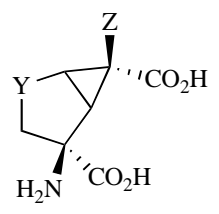

$\mathrm{Y}=\mathrm{CH}_{2}, \mathrm{Z}=\mathrm{H}: \mathrm{LY} 354740$

$\mathrm{Y}=\mathrm{O}, \mathrm{Z}=\mathrm{H}: \mathrm{LY} 379268$

$\mathrm{Y}=\mathrm{S}, \mathrm{Z}=\mathrm{H}: \mathrm{LY} 389795$

$\mathrm{Y}=\mathrm{C}=\mathrm{O}, \mathrm{Z}=\mathrm{F}: \mathrm{MGS} 0028$

Fig. (1). Competitive mGlu2/3 receptor agonists. 
<smiles>[X]c1ccc(N(Cc2cccnc2)S(=O)(=O)CC(F)(F)F)cc1[X]</smiles><smiles>COc1ccccc1OC(C)C</smiles><smiles>[Y]=[Ti][AsH2]</smiles>

Fig. (2). mGlu2 receptor potentiators.

upon stimulation with AMN082 [98], which, in turn, may lead to mGlu 7 receptor blockade. There are several issues to be resolved regarding the neuronal mechanisms by which mGlu7 receptor affects depressive states, including its sites of action and relationships with other glutamate receptors.

\section{CHEMISTRY}

\section{1. mGlu2/3 Receptor Agonist/mGluR2 Receptor Potentiators}

In initial studies investigating the functions of $\mathrm{mGlu} 2 / 3$ receptors, L-CCG-I, ACPD and DCG-IV were used as nonselective ligands and conformationally restricted glutamate analogs (Fig. 1) [99-101]. LY354740 was described in 1997 as the first potent and selective agonist for $\mathrm{mGlu} 2 / 3$. It activates the mGlu2 $\left(\mathrm{EC}_{50}=5 \mathrm{nM}\right)$ and mGlu3 $\left(\mathrm{EC}_{50}=24 \mathrm{nM}\right)$ receptors in vitro and has potent pharmacological effects in animals [102]. LY354740 is a comformationally restricted bicycloamino acid, $(1 S, 2 S, 5 R, 6 S)$-2-aminobicyclo[3.1.0]hexane-2,6-dicarboxylic acid. For this type of bicyloamino acid, in the 2-position of the bicyclohexane ring, LY379268 has an oxygen atom, LY389795 has a sulfur atom, and MGS0028 has an oxo group [23, 103]. These compounds have been reported to have highly potent $\mathrm{mGlu} 2 / 3$ receptors agonist activities.

Two compound series have been reported as mGlu2 receptor allosteric potentiators (Fig. 2). The first series includes an allosteric modulator of the mGlu2 receptor from an $\mathrm{N}$-aryl pyrinin-3-ylmethylsulfonamide derivative, 4MPPTS [104]. In this compound type, cyPPTS is a very potent potentiator $(24 \mathrm{nM})$ [105]. Another series of compounds results from 4'-alkoxyacetophenone derivatives, and is typified by compound $\mathbf{1}$. Compound $\mathbf{1}$ is a selective mGlu2 receptor potentiator $(300 \mathrm{nM})$ with no allosteric activities against mGlu1, 3, 4, 5, 7 or 8 [106, 107].

\section{2. mGlu2/3 Receptor Antagonists}

Compared with other receptor subtypes, mGlu2/3 receptor antagonists have rarely been reported in the literature. In 1996, a glutamate analog, LY341495, was disclosed as a selective competitive mGlu 2/3 receptor antagonist in a patent application (Fig. 3) [108]. LY341495 has nanomolar affinities for mGlu $2 / 3$ receptors [109, 110]. MGS0039 containing a bicyclo[3.1.0]hexane ring system<smiles>CCCc1c(OCCCCOc2ccc(-c3nn[nH]n3)cc2)ccc(C(C)=O)c1O</smiles>

was reported to have nanomolar affinities for mGlu $2 / 3$ receptors [111]. The series of $m$ Glu $2 / 3$ receptors antagonists that have amino acid moieties are found at low levels in the CNS. In fact, ester prodrugs of MGS0039 are reported to deliver MGS0039 after hydrolytic release of the ester prodrugs [112].

New classes of mGlu 2 antagonists without amino acid moieties have been identified. Triazole derivative $\mathbf{2}$ was reported as an antagonist with moderate affinity for the mGlu 2 receptor $(\mathrm{Ki}=0.1 \mu \mathrm{M})$ [113]. A series of patents were published on benzodiazepine derivative 3 , which reportedly had a very low nanomolar affinity for the mGlu 2 receptor [114]. Thiazolopyrimidine derivative 4 and pyrrazolopyrimidine derivative $\mathbf{5}$ represented novel structural templates for mGlu 2 receptor antagonists [115 - 119]. Thiazolopyrimidine derivatives showed moderate binding affinity for the mGlu 2 receptor, while pyrrazolopyrimidine had low nanomolar affinity. Recently, a structurally different mGlu 2 receptor antagonist, imidazole 6, was disclosed (binding affinity for mGlu 2 receptor $\left(\mathrm{IC}_{50}=7 \mathrm{nM}\right)$ [120]. These new classes of mGlu 2 receptor antagonists have limited disclosures regarding the details of their subtype selectivities, their modes of binding, including activities as competitive and non-competitive modulators, binding sites, and their pharmacology.

\section{3. mGlu1 Receptor Antagonists}

Competitive mGlu1 receptor antagonists are poorly represented in the literature. Fig. (4) shows some selective competitive mGlu1 receptor antagonists. These antagonists are analogs of glutamine and phenylglycine. $(S)-4-C P G$, a phenylglycine analog, is a selective antagonist with weak effects for the mGlu2 receptor [121]. The 2-Methyl analog of $(S)-4-C P G$, LY367385, is more potent and more selective than $(S)-4-C P G$ for the mGlul receptor, without any effects for the group II mGlu receptors [122]. AIDA, a conformationally restricted analog between the phenyl group and an amino acid carbon, selectively antagonizes the mGlu 1 receptor, with weak effects for the mGlu5 and 2 receptors $[123,124]$. Compound 7 , with a replacement in the phenyl ring of $(S)-4-\mathrm{CPG}$ with cuban is a potent, selective antagonist for the mGlul receptor $[125,126]$. Since competitive mGlu1 receptor antagonists show poor 
potencies, selectivities, and levels of CNS exposure, they have not yet become clinically useful therapeutic agents $[127,128]$.

Negative allosteric mGlu1 receptor modulators are structurally different from glutamate and phenylglycine. Several different structures are shown in Fig. (5.) CPCCOEt was first identified as a negative allosteric modulator in the late 1990s [129-131]. Then, several new classes of mGlu1 receptor antagonists that were structurally distinct from CPCCOEt were identified. BAY36-7620, containing butyrolactone, is a potent $\left(\mathrm{IC}_{50}=160 \mathrm{nM}\right)$ and selective antagonist for the mGlu1 receptor. It inhibits $>60 \%$ of mGlu1a receptor constitutive activity $\left(\mathrm{IC}_{50}=380 \mathrm{nM}\right)$. Thus, BAY36-7620 was the first mGlu1 receptor inverse agonist to be described [132]. At about the same time, some different types of heteroaromatic compounds were reported. Compound $\mathbf{8}$ containing an indole ring shows a low micromole affinity for the mGlu1 receptor, and pyridine ring fused indole derivatives $\mathbf{9}$ is also a low affinity mGlu1 receptor antagonist [133, 134]. A series of patents were published on YM-29818 containing a thiazolobenzimidazole ring [135-137]. The specificity of YM-29818 for the mGlu1 receptor $\left(\mathrm{IC}_{50}=16 \mathrm{nM}\right)$ included subtypes 2 to 7 , as well as several other receptors, transporters, and ion channel targets.

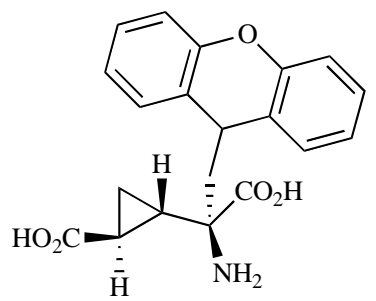

LY341495
From in vivo experiments, orally administered YM-298198 showed a significant analgesic effect in streptozotocininduced hyperalgesic mice $(30 \mathrm{mg} / \mathrm{kg}$ ) [138]. In 2006, in a series of tricycloaromatics, novel pyridothienopyrimidine derivatives were reported as mGlu1 receptor antagonists, such as 10, that had $\mathrm{IC}_{50}$ values of $<50 \mathrm{nM}$ [139].

Quinoline and quinoxaline derivatives, such as $\mathbf{1 1}$ and 12, were found to be mGlul receptor antagonists. Compound $\mathbf{1 1}$ exhibited high activity for the mGlu1 receptor $\left(\mathrm{IC}_{50}=2.97 \mathrm{nM}\right)$ [140]. Compound 12 had good affinity for the mGlu1 receptor $\left(\mathrm{IC}_{50}=52 \mathrm{n} \mathrm{M}\right.$ ) and no affinity for mGlu5 receptor $\left(\mathrm{IC}_{50}=7289 \mathrm{nM}\right)$ [141].

A series of heteroaromatics and cycloamine derivatives, 13-19, were also published. Benzoazepine and pyrimidine derivative 13 has an $\mathrm{IC}_{50}$ value of $3 \mathrm{nM}$ for binding affinity to the mGlu 1 receptor, an $\mathrm{IC}_{50}$ value of $9 \mathrm{nM}$ [142]. Pyrazine analog 14 also shows high binding affinity for the mGlu1 receptor $\left(\mathrm{IC}_{50}=6 \mathrm{nM}\right)$ [143]. Piperazine derivative 17, modified from benzoazepine moiety in $\mathbf{1 4}$ to phenylpiperazine, is a potent negative allosteric modulator of the mGlu1 receptor $\left(\mathrm{IC}_{50}=23 \mathrm{nM}\right)$ [144]. In 2006, $N$-pyridyland $\mathrm{N}$-phenyl-piperazine derivatives were identified. Compounds 16 and $\mathbf{1 7}$ had reported affinities for the mGlu1 receptor of $6.9 \mathrm{nM}$ and $38 \mathrm{nM}$, respectively, and antagonized<smiles>N[C@@]1(C(=O)O)C(OCc2ccc(Cl)c(Cl)c2)CC2C1[C@]2(F)C(=O)O</smiles>

MGS0039<smiles>Clc1ccc(/C(=C/n2cncn2)OC2CCCCC2)c(Cl)c1</smiles>

2<smiles>O=C(Nc1cccc(S(=O)(=O)N2CCOCC2)c1)c1cnn2c(C(F)(F)F)cc(-c3ccc(C(F)(F)F)cc3)nc12</smiles><smiles>COc1ccc(C2C(C(C)=O)=C(C)N=C3SC(c4c(Cl)cccc4Cl)=CN32)cc1</smiles>

4

Fig. (3). Antagonists of mGlu 2 receptor.<smiles>Cc1cc(-c2cccc(C3=Nc4cc(C(F)(F)F)c(N(C)C)cc4NC(=O)C3)c2)ccn1</smiles>

3<smiles>Cn1c(-c2c(Cl)cccc2Cl)nc(-c2ccncc2)c1-c1ccc(Cl)cc1</smiles>

6 
the increase of locomotor activity in rats with amphetamine at a dose of $30 \mathrm{mg} / \mathrm{kg}[145,146]$.

Recently, novel diaryl substituted 5-membered heteroaromatic derivatives 18 and 19 were disclosed. Compound 18 exhibited an $\mathrm{IC}_{50}$ value of $2.3 \mathrm{nM}$ and activity against the disruption of prepulse inhibition in methamphetamine treated rats at $1-10 \mathrm{mg} / \mathrm{kg}[147,148]$.

\section{4. mGlu5 Receptor Agonists/mGlu5 Receptor Potentiators}

3,5-DHPG was identified as the first group I receptor selective agonist (Fig. 6). However, 3,5-DHPG lacks subtype selectivity and has low potency [149, 150]. In 1999, compounds $\mathbf{2 0}$ and $\mathbf{2 1}$ were described as selective mGlur5 receptor agonists. Their $\mathrm{EC}_{50}$ values were $11 \mathrm{nM}$ and $49 \mathrm{nM}$, respectively [151]. Their apparent higher potency and selectivity for mGlu5 receptor might make these compounds important new pharmacological tools. Despite these significant advances, highly potent and subtype-selective competitive mGlu receptor agonists have not been identified.

In an attempt to overcome the low potency, low selectivity, and poor blood-brain barrier permeation of most mGlu receptor ligands, investigations of non-competitive mGlu5 receptor modulators began in the mid-1990s. mGlu5 receptor positive allosteric modulators began to be developed after 2000. Three different structural types of mGlu5 receptor positive allosteric modulators were reported: DFB, CDPPB, and CPPHA [152-154]. These modu-lators do not affect ligand binding to the orthosteric glutamate binding site, but potentiate its response to glutamate. DFB and CDPPB bind to the MPEP site and displace binding of radioligand to a well-characterized binding site for MPEP $[155,156]$. Thus, some reports indicate that these compounds have antipsychotic-like effects [156, 157].

In 2005, a fourth structural series, ADX-47273, was reported by Addex pharm with similar properties [158, 159].

\section{5. mGlu5 Receptor Antagonists}

The first mGlu 5 receptor antagonists were identified from agonists having either a glutamate or a phenylglycine moiety (Fig. 7). These antagonists bind competitively at the glutamate-binding site. These early competitive antagonists lacked subtype selectivity. For example, phenyglycine derivative 22 showed weak antagonist activity for human mGlu5 receptor, as well as antagonist activity for the mGlu1 receptor [121].

In contrast, the most widely known pharmacological tool for showing the therapeutic potential of mGlu5 receptor antagonists is MPEP. Both MPEP and the structurally related MTEP are highly selective antagonists for the mGlu1 receptor [158-160]. These compounds are structurally distinct from glutamate and bind to an allosteric site in the transmembrane domain. After identifying MPEP and MTEP, many derivatives were disclosed in patents and in the literature. Several substitutions were introduced into the 3position of the phenyl ring of MPEP and the 5-position of the pyridine ring of MTEP.

Compound 23, a derivative with a methoxy group in the 3-position of the benzene ring of MPEP, shows a similar potency for the mGlu5 receptor as MTEP. The methoxy group of $\mathbf{2 3}$ can be easily radiolabeled by a reaction of the phenolic intermediate with $\left[{ }^{3} \mathrm{H}\right]$-methyl iodide. This radioligand with high specific activity and radiochemical purity is useful for labeling the mGlu5 receptor [161]. Introduction of a methoxymethyl group into the 5-pyridyl position of MTEP gives $\mathbf{2 4}$ with a similar potency to MTEP [162]. A radioactive compound of $\mathbf{2 4}$ has also been synthesized and used for in vitro binding assays using either rat brain tissues or cells that express recombinant human mGlu5 receptors [163].

Additional modifications of the pyridine ring of MTEP were investigated. Introduction of pyridine at the 5-pyridyl position of MTEP and transformation of the isoquinoline ring from the pyridine ring of MTEP gave 25 and 26, respectively. These compounds show high in vitro potencies $\left(\mathbf{2 5}, \mathrm{IC}_{50}=22 \mathrm{nM}, \mathrm{Ki}=28 \mathrm{nM} ; \mathbf{2 6}, \mathrm{IC}_{50}=20 \mathrm{nM}\right)[164$, 165]. Further explorations of mGlu5 receptor agonists by high-through-put-screening and optimization led to a novel series of pyridinyl-alkyne derivatives that were structurally related to MPEP (25: $\left.\mathrm{IC}_{50}=15 \mathrm{nM}\right)$ [166]. Recently, a novel phenyl-alkyne derivative was disclosed as an mGlu5 receptor antagonist $\left(\mathbf{2 8}\right.$ : $\left.\mathrm{IC}_{50}=290 \mathrm{nM}\right)$ [167].

Aryl benzoxazole 29 was identified by high-through-putscreening as a potent mGlu5 receptor antagonist [168]. Compound 30 containing an oxazole ring substituted with an aryl group was disclosed in a patent [169]. However, 29 was not suitable for in vivo studies due to its poor solubility and<smiles>[R]c1cc(C(=O)O)ccc1[C@H](N)C(=O)O</smiles>

$\mathrm{R}=\mathrm{H}:(\mathrm{S})-4-\mathrm{CPG}$

$\mathrm{R}=\mathrm{Me}: \mathrm{LY} 367385$

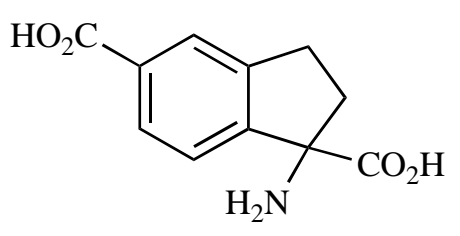

AIDA

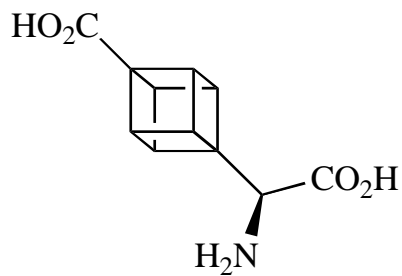

7

Fig. (4). Competitive mGlu1 receptor antagonists. 
<smiles>CCOC(=O)[C@@]12C[C@@H]1/C(=N\O)c1ccccc1O2</smiles>

CPCCOOEt<smiles>C=C1C[C@H]2COC(=O)[C@@]2(Cc2ccc3ccccc3c2)C1</smiles>

BAY36-7620<smiles>CCn1c2ccccc2c2cc(C(=O)O)c(N3CCOCC3)nc21</smiles><smiles>CN(C)c1ccnc2sc3c(=O)n(-c4ccc5c(c4)OCO5)cnc3c12</smiles>

10

YM-298198<smiles>CCc1cc2cc(C(=O)C3CCC(OC)CC3)ccc2nc1C</smiles>

11<smiles>CCc1nc(C#N)c(N2CCc3ccccc3CC2)nc1C</smiles>

14<smiles>CC(C)(C)COC(=O)N1CCN(c2cccc(-c3ccccc3F)c2)C(=O)C1</smiles>

17<smiles>CC1CCC(NC(=O)c2cnc3c(n2)CC[C@H](C)CC3)CC1</smiles>

12<smiles>CCn1c(N)nc(N2CCc3ccccc3CC2)c(C#N)c1=O</smiles>

13<smiles>Cc1ccnc(N2CCN(C(=O)OCC(C)(C)C)CC2)c1</smiles>

16

15<smiles>O=C1CCCc2nc(-c3ncc(-c4cccc(Br)c4)s3)ccc21</smiles>

18<smiles>Cc1c(-c2ccc3c(c2)CC2(CC2)C3=O)nnn1-c1cnccc1F</smiles>

19

Fig. (5). Non-competitive mGlu1 receptor antagonists.

poor pharmacokinetic profile (oral bioavailability $\mathrm{F}=0.7 \%$ ) [168]. Compound 29 was modified based on SAR studies of the common structural features of 29, oxazole derivative 30, MPEP and MTEP to reveal a series of azole derivatives containing a pyridine and 1 or 2 phenyl rings, such as 31 [170].

Recently, some new classes of mGlu 5 receptor antagonists, dipyridyl amine 32, thiopyrimide 33, and arylmethoxypyrimide derivative $\mathbf{3 4}$, were identified by highthrough-put screening $\left(\mathbf{3 2} ; \mathrm{IC}_{50}=12 \mathrm{nM}, \mathbf{3 3} ; \mathrm{IC}_{50}=80 \mathrm{Nm}\right.$ 34; $\mathrm{Ki}=1 \mathrm{nM})$. Compounds $\mathbf{3 2}$ and $\mathbf{3 4}$ have low to moderate oral bioavailabilities $(\mathbf{3 2} ; \mathrm{F}=38 \%, \mathbf{3 4} ; \mathrm{F}=4.7 \%)$.

\section{6. mGlu7 Receptor Ligands}

To date, mGlu7 ligands are poorly represented in the literature. Only a mGlu7 receptor-selective agonist has been described, AMN082 (Fig. 8) [171, 172]. This compound was identified using high-throughput screening as the first full allosteric agonist for the mGlu7 receptor. This compound is structurally unrelated to any known mGlu receptor ligand. AMN082 has a unique mechanism of action by fully activating mGlu7 receptor through an allosteric site far removed from the glutamate-binding pocket [98].

There are only a limited number of selective mGlu7 receptor antagonists. MDIP was identified by high- 


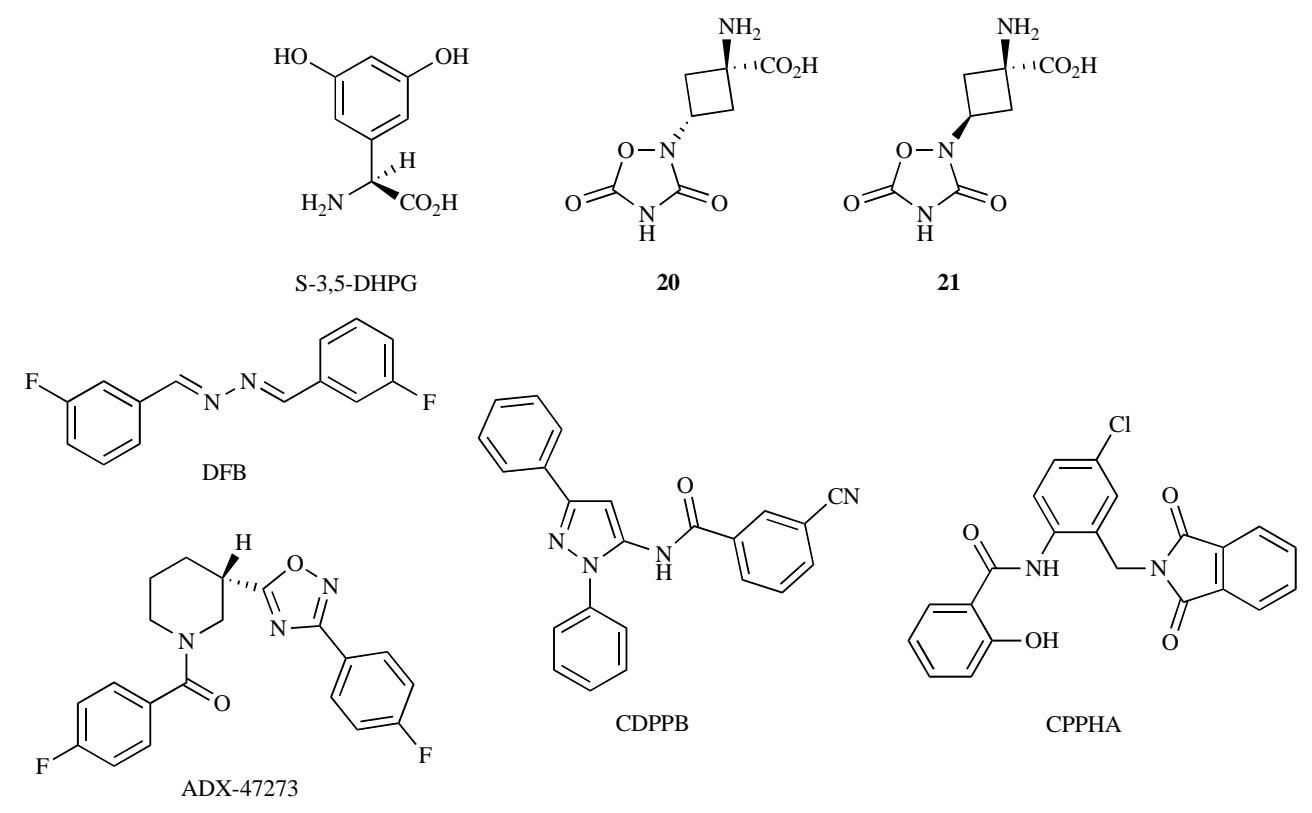

Fig. (6). mGlu5 receptor agonists.<smiles>NC(C(=O)O)c1ccc(C(=O)O)c(O)c1</smiles>

22<smiles>Cc1cccc(C#Cc2ccccc2)n1</smiles>

MPEP<smiles>Cc1nc(C#Cc2cccnc2)cs1</smiles>

MTEP<smiles>COc1cccc(C#Cc2cccc(C)n2)c1</smiles>

23<smiles>COCc1cncc(C#Cc2csc(C)n2)c1</smiles>

24<smiles>Cc1cccc(C#CCOc2ccc(Cl)c(Cl)c2)n1</smiles>

27<smiles>N#Cc1ccc(-c2nc3ccccc3o2)cc1Cl</smiles>

29<smiles>CCOc1cc(-c2cccnc2)cnc1Nc1cccc(C)n1</smiles>

32<smiles>Cc1nc(C#Cc2cncc(-c3ccccn3)c2)cs1</smiles>

25<smiles>CCCC(O)(C#Cc1cccc(Cl)c1)CCC</smiles>

30<smiles>Fc1ccc(-c2nccc(Sc3ccc(Cl)c(Cl)c3)n2)nc1</smiles>

33<smiles>Cc1nc(C#Cc2cncc3ccccc23)cs1</smiles>

26<smiles>COc1ccccc1CO</smiles><smiles>N#Cc1cccc(-n2nnc(-c3ccccn3)n2)c1</smiles>

31<smiles>Cc1cc(C#N)cc(OCc2cccc(Cl)c2)n1</smiles>

34

Fig. (7). Antagonists of mGlu 5 receptor. 
<smiles>Clc1ccc(C(NCCNC(c2ccccc2)c2ccccc2)c2ccccc2)cc1</smiles>

AMN082<smiles>Cn1c(-c2ccccc2)cc2onc(-c3ccccc3)c2c1=O</smiles>

MDIP<smiles>COc1ccc(-c2cc3onc(-c4ccncc4)c3c(=O)n2C)cc1</smiles>

MMPIP

Fig. (8). mGlu 7 receptor ligands.

Table 2. Possible Therapeutic Indications for Agents Acting on mGlu Receptors

\begin{tabular}{|c|c|c|c|}
\hline Group & Subtype & & Possible Therapeutic Indications \\
\hline \multirow[t]{3}{*}{ Group I } & mGlu1 & agonists/PAMs & cognitive disorders \\
\hline & \multirow[t]{2}{*}{ mGlu5 } & agonists/PAMs & schizophrenia, cognitive disorders \\
\hline & & antagonists & $\begin{array}{l}\text { depression/anxiety, pain, drug addiction, } \\
\text { gastroesphageal reflux disease, } \\
\text { Parkinson's disease, migrain }\end{array}$ \\
\hline \multirow[t]{4}{*}{ Group II } & \multirow[t]{2}{*}{ mGlu2 } & agonists/PAMs & schizophrenia, anxiety \\
\hline & & antagonists & depression/anxiety, cognitive disorders \\
\hline & \multirow[t]{2}{*}{ mGlu3 } & agonists/PAMs & schizophrenia \\
\hline & & antagonists & $?$ \\
\hline \multirow{5}{*}{ Group III } & mGlu7 & antagonists & depression/anxiety (?) \\
\hline & \multirow[t]{2}{*}{ mGlu6 } & agonists/PAMs & $?$ \\
\hline & & antagonists & $?$ \\
\hline & \multirow[t]{2}{*}{ mGlu8 } & agonists/PAMs & depression/anxiety (?) \\
\hline & & antagonists & $?$ \\
\hline
\end{tabular}

throughput screening, and MMPIP was synthesized by chemical modification of the phenyl group in the isoxazole ring system to a pyridyl group. In a cAMP assay, MDIP and MMPIP had $\mathrm{IC}_{50}$ values of $99 \mathrm{nM}$ and $220 \mathrm{nM}$, respectively. The inhibitory modes of these compounds are noncompetitive and allosteric, and MMPIP appears to have an inverse agonist activity [173].

\section{CONCLUSIONS AND FUTURE DIRECTIONS}

Accumulating evidence indicates that $\mathrm{mGlu}$ receptors are significantly involved in psychiatric disorders and may serve as intriguing targets for drug discovery for the treatment of psychiatric disorders (Table 2). Among the mGlu receptors, mGlu2/3 receptor agonists have been proven to be effective for the treatment of not only schizophrenia, but also certain anxiety disorders in clinical settings. LY354740 was shown to exert anxiolytic effects in a fear-potentiated startle model in human volunteers [7], and LY354740 or LY544344, a prodrug of LY354740, showed efficacy in human anxiety models (panic provocation induced by the intravenous injection of cholecystokinin tetrapeptide or $\mathrm{CO}_{2}$ challenge) $[8,9]$. Therefore, together with the recent remarkable findings that LY2140023, a prodrug of the mGlu2/3 receptor agonist LY404039, provided improvements for both positive and negative symptoms of schizophrenia, mGlu2/3 receptor stimulation has paved the way for developing novel approaches beyond monoamine therapy for the treatment of psychiatric disorders, such as schizophrenia and anxiety.

Preclinical evidence is accumulating on the efficacy of mGlu2/3 receptor antagonists (depression), mGlu5 receptor agonists/potentiators (schizophrenia) and mGlu5 receptor antagonists (depression) in several animal models. Although a large number of patents for these targets have been published, there are few compounds that have entered clinical trials. Human proof-of-concept studies with compounds acting on the above mGlu receptors are necessary in order to address the utility of these mGlu receptors for treating psychiatric disorders. 


\section{REFERENCES}

[1] Nakanishi, S. Molecular diversity of glutamate receptors and implications for brain function. Science, 1992, 258, 597-603.

[2] Nakanishi, S.; Masu, M. Molecular diversity and functions of glutamate receptors. Ann. Rev. Biophys. Biomol. Struct., 1994, 23, 319-348.

[3] Pin, J. P.; Duvoisin, R. The metabotropic glutamate receptors: structure and fuctions. J. Neurochem., 1992, 58, 1184-1186.

[4] Schoepp, D. D.; Conn, P. J. Metabotropic glutamate receptors in brain function and pathology. Trend Pharmacol. Sci., 1993, 14, 1320.

[5] Conn, P. J.; Pin, J. P. Pharmacology and functions of metabotropic glutamate receptors. Ann. Rev. Pharmacol. Toxicol., 1997, 37, 205237.

[6] Patil, S.T.; Zhang, L.; Martenyi, F.; Lowe, S. L.; Jackson, K. A.; Andreev, B. V.; Avedisova, A. S.; Bardenstein, L. M.; Gurovich, I. Y.; Morozova, M. A.; Mosolov. S. N.; Neznanov, N. G.; Reznik, A. M.; Smulevich, A. B.; Tochilov, V. A.; Johnson, B. G.; Monn, J. A.; Schoepp, D. D. Activation of $m G l u 2 / 3$ receptors as a new approach to treat schizophrenia: a randomized Phase 2 clinical trial. Nat. Med., 2007, 13(9), 1102-1107.

[7] Grillon, C.; Cordova, J.; Levine, L. R.; Morgan, C. A. 3rd. Anxiolytic effects of a novel group II metabotropic glutamate receptor agonist (LY354740) in the fear-potentiated startle paradigm in humans. Psychopharmacology (Berl), 2003, 168, 446454.

[8] Kellner, M.; Muhtz, C.; Stark, K.; Yassouridis, A.; Arlt, J.; Wiedemann, K. Effects of a metabotropic glutamate(2/3) receptor agonist (LY544344/LY354740) on panic anxiety induced by cholecystokinin tetrapeptide in healthy humans: preliminary results. Psychopharmacology (Berl), 2005, 179, 310-315.

[9] Schoepp, D. D.; Wright, R. A.; Levine, L, R.; Gaydos, B.; Potter, W. Z. LY354740, an mGlu2/3 receptor agonist as a novel approach to treat anxiety/stress. Stress, 2003, 6, 189-97.

[10] Kim, J. S.; Kornhuber, H. H.; Schmid-Burgk, W.; Holzmüller, B. Low cerebrospinal fluid glutamate in schizophrenic patients and a new hypothesis on schizophrenia. Neurosci. Lett., 1980, 20, 379382 .

[11] Tsai, G.; Passani, L. A.; Slusher, B. S.; Carter, R.; Baer, L.; Kleinman, J. E.; Coyle, J. T. Abnormal excitatory neurotransmitter metabolism in schizophrenic brains. Arch. Gen. Psychiatry, 1995, 52, 829-836.

[12] Faustman, W. O.; Bardgett, M.; Faull, K. F.; Pfefferbaum, A.; Csernansky, J. G. Cerebrospinal fluid glutamate inversely correlates with positive symptom severity in unmedicated male schizophrenic/schizoaffective patients. Biol. Psychiatry, 1999, 45, 68-75.

[13] Javitt, D. C.; Zukin, S. R. Recent advances in the phencyclidine model of schizophrenia. Am. J. Psychiatry, 1991, 148, 1301-1308.

[14] Krystal, J.H., Karper, L.P., Seibyl, J.P., Freeman, G.K., Delaney, R., Bremner, J.D., Heninger, G. R.; Bowers, M. B. Jr.; Charney, D. S. Subanesthetic effects of the noncompetitive NMDA antagonist, ketamine, in humans. Psychotomimetic, perceptual, cognitive, and neuroendocrine responses. Arch. Gen. Psychiatry, 1994, 51, 199214.

[15] Lahti, A. C.; Weiler, M. A.; Tamara Michaelidis, B. A.; Parwani, A.; Tamminga, C. A. Effects of ketamine in normal and schizophrenic volunteers. Neuropsychopharmacology, 2001, 25, 455-467.

[16] Newcomer, J. W.; Farber, N. B.; Jevtovic-Todorovic, V.; Selke, G.; Melson, A. K.; Hershey, T.; Craft, S.; Olney, J. W., Ketamineinduced NMDA receptor hypofunction as a model of memory impairment and psychosis. Neuropsychopharmacology, 1999, 20, 106-118.

[17] Geyer, M. A.; Krebs-Thomson, K.; Braff, D. L.; Swerdlow, N. R. Pharmacological studies of prepulse inhibition models of sensorimotor gating deficits in schizophrenia: a decade in review. Psychopharmacology (Berl), 2001, 156, 117-154.

[18] Gleason, S. D.; Shannon, H. E. Blockade of phencyclidine-induced hyperlocomotion by olanzapine, clozapine and serotonin receptor subtype selective antagonists in mice. Psychopharmacology (Berl), 1997, 129, 79-84.
[19]

Mohn, A. R.; Gainetdinov, R. R.; Caron, M. G.; Koller, B. H. Mice with reduced NMDA receptor expression display behaviors related to schizophrenia. Cell, 1999, 98, 427-436.

[20] Moghaddam, B.; Adams, B. W. Reversal of phencyclidine effects by a group II metabotropic rceptor agonists in rats. Science, 1998, 281, 1349-1352.

[21] Rorick-Kehn, L. M.; Johnson, B. G..; Knitowski, K. M. Salhoff, C. R.; Witkin, J. M.; Perry, K. W.; Griffey, K. I.; Tizzano, J. P.; Monn, J. A.; McKinzie, D. L.; Schoepp, D. D. In vivo pharmacological characterization of the structurally novel, potent, selective mGlu2/3 receptor agonist LY404039 in animal models of psychiatric disorders. Psychopharmacology (Berl), 2007, 193, 121136.

[22] Cartmell, J.; Monn, J.; Schoepp, D. D. Attenuation of specific PCPevoked behaviors by the potent $\mathrm{mGluR} 2 / 3$ receptor agonist, LY379268 and comparison with the atypical antipsychotic, clozapine. Psychopharmacology (Berl), 2000, 148, 423-429.

[23] Nakazato, A; Kumagai, T.; Sakagami, K.; Yoshikawa, R.; Suzuki, Y.; Chaki, S.; Ito, H.; Taguchi, T.; Nakanishi, S.; Okuyama, S. Synthesis, SARs, and pharmacological characterization of 2-amino3 or 6-fluorobicyclo[3.1.0]hexane-2,6-dicarboxylic acid derivatives as potent, selective, and orally active group II metabotropic glutamate receptor agonists. J. Med. Chem., 2000, 43, 4893-4909.

[24] Galici, R.; Echemendia, N. G.; Rodriguez, A. L.; Conn, P. J. A selective allosteric potentiator of metabotropic glutamate (mGlu) 2 receptors has effects similar to an orthosteric mGlu2/3 receptor agonist in mouse models predictive of antipsychotic activity. $J$. Pharmacol. Exp. Ther., 2005, 315, 1181-1187.

[25] Takamori, K.; Hirota, S.; Chaki, S.; Tanaka, M. Antipsychotic action of selective group II metabotropic glutamate receptor agonist MGS0008 and MGS0028 on conditioned avoidance responses in the rat. Life Sci., 2003, 73, 1721-1728.

[26] Fell, M. J.; Svensson, K. A.; Johnson, B. G.; Schoepp, D. D. Evidence for the role of metabotropic glutamate (mGlu)2 not mGlu3 receptors in the preclinical antipsychotic pharmacology of the mGlu2/3 receptor agonist (-)-(1R,4S,5S,6S)-4-amino-2sulfonylbicyclo[3.1.0] hexane-4,6-dicarboxylic acid (LY404039). $J$. Pharmacol. Exp. Ther., 2008, 326, 209-217.

[27] Harich, S.; Gross, G.; Bespalov, A. Stimulation of the metabotropic glutamate $2 / 3$ receptor attenuates social novelty discrimination deficits induced by neonatal phencyclidine treatment. Psychopharmacology (Berl), 2007, 192, 511-519.

[28] Higgins, G. A.; Ballard, T.M.; Kew, J. N.; Richards, J. G.; Kemp, J. A.; Adam, G.; Woltering, T.; Nakanishi, S. Mutel, V. Pharmacological manipulation of mGlu2 receptors influences cognitive performance in the rodent. Neuropharmacology, 2004, 46, 907-917.

[29] Schlumberger, C.; Schäfer, D.; Barberi, C.; Morè, L.; Nagel, J.; Pietraszek, M.; Schmidt, W. J.; Danysz, W. Effects of a metabotropic glutamate receptor group II agonist LY354740 in animal models of positive schizophrenia symptoms and cognition. Behav. Pharmacol., 2009, 20, 56-66.

[30] Henry, S. A.; Lehmann-Masten, V.; Gasparini, F.; Geyer, M. A.; Markou, A. The mGluR5 antagonist MPEP, but not the mGluR2/3 agonist LY314582, augments PCP effects on prepulse inhibition and locomotor activity. Neuropharmacology, 2002, 43, 1199-1209.

[31] Calcagno, E.; Carli, M.; Baviera, M.; Invernizzi, R. W. Endogenous serotonin and serotonin2C receptors are involved in the ability of M100907 to suppress cortical glutamate release induced by NMDA receptor blockade. J. Neurochem., 2009, 108, 521-532.

[32] Lorrain, D. S.; Baccei, C. S.; Bristow, L. J.; Anderson, J. J.; Varney, M. A. Effects of ketamine and $N$-methyl-D-aspartate on glutamate and dopamine release in the rat prefrontal cortex: modulation by a group II selective metabotropic glutamate receptor agonist LY379268. Neuroscience, 2003, 117, 697-706.

[33] Gozzi, A.; Large, C. H.; Schwarz, A.; Bertani, S.; Crestan, V.; Bifone, A. Differential effects of antipsychotic and glutamatergic agents on the phMRI response to phencyclidine. Neuropsychopharmacology (Berl), 2008, 33, 1690-1703.

[34] Greenslade, R. G.; Mitchell, S. N. Selective action of (-)-2-oxa-4aminobicyclo[3.1.0]hexane-4,6-dicarboxylate (LY379268), a group II metabotropic glutamate receptor agonist, on basal and 
phencyclidine-induced dopamine release in the nucleus accumbens shell. Neuropharmacology, 2004, 47, 1-8.

[35] Cartmell, J.; Perry, K. W.; Salhoff, C. R.; Monn, J. A.; Schoepp, D. D. Acute increases in monoamine release in the rat prefrontal cortex by the mGlu2/3 agonist LY379268 are similar in profile to risperidone, not locally mediated, and can be elicited in the presence of uptake blockade. Neuropharmacology, 2001, 40, 847855.

[36] Gewirtz, J. C.; Marek, G. J. Behavioral evidence for interactions between a hallucinogenic drug and group II metabotropic glutamate receptors. Neuropsychopharmacology, 2000, 23, 569-576.

[37] Benneyworth, M. A.; Xiang, Z.; Smith, R. L.; Garcia, E. E.; Conn, P. J.; Sanders-Bush, E. A selective positive allosteric modulator of metabotropic glutamate receptor subtype 2 blocks a hallucinogenic drug model of psychosis. Mol. Pharmacol., 2007, 72, 477-484.

[38] González-Maeso, J.; Ang, R. L.; Yuen, T.; Chan, P.; Weisstaub, N. V.; López-Giménez, J. F.; Zhou, M.; Okawa, Y.; Callado, L. F.; Milligan, G.; Gingrich, J. A.; Filizola, M.; Meana, J. J.; Sealfon, S. C. Identification of a serotonin/glutamate receptor complex implicated in psychosis. Nature, 2008, 452, 93-97.

[39] Chan, M. H.; Chiu, P. H.; Sou, J. H.; Chen, H. H. Attenuation of ketamine-evoked behavioral responses by mGluR5 positive modulators in mice. Psychopharmacology (Berl), 2008, 198, 141148.

[40] Kinney, G. G.; Burno, M.; Campbell, U. C.; Hernandez, L. M.; Rodriguez, D.; Bristow, L. J.; Conn, P. J. Metabotropic glutamate subtype 5 receptors modulate locomotor activity and sensorimotor gating in rodents. J. Pharmacol. Exp. Ther., 2003, 306, 116-123.

[41] Kinney, G. G.; O'Brien, J. A.; Lemaire, W.; Burno, M.; Bickel, D. J.; Clements, M. K.; Chen, T. B.; Wisnoski, D. D.; Lindsley, C. W.; Tiller, P. R.; Smith, S.; Jacobson, M. A.; Sur, C.; Duggan, M. E.; Pettibone, D. J.; Conn, P. J.; Williams, D. L. Jr. A novel selective positive allosteric modulator of metabotropic glutamate receptor subtype 5 has in vivo activity and antipsychotic-like effects in rat behavioral models. J. Pharmacol. Exp. Ther., 2005, 313, 199-206.

[42] Liu, F.; Grauer, S.; Kelley, C.; Navarra, R.; Graf, R.; Zhang, G.; Atkinson, P. J.; Popiolek, M.; Wantuch, C.; Khawaja, X.; Smith, D.; Olsen, M.; Kouranova, E.; Lai, M.; Pruthi, F.; Pulicicchio, C.; Day, M.; Gilbert, A.; Pausch, M. H.; Brandon, N. J.; Beyer, C. E.; Comery, T. A.; Logue, S.; Rosenzweig-Lipson, S.; Marquis, K. L. ADX47273 [S-(4-fluoro-phenyl)-\{3-[3-(4-fluoro-phenyl)-[1,2,4]oxadiazol-5-yl]-piperidin-1-yl\}-methanone]: a novel metabotropic glutamate receptor 5-selective positive allosteric modulator with preclinical antipsychotic-like and procognitive activities. $J$. Pharmacol. Exp. Ther., 2008, 327, 827-839.

[43] Uslaner, J. M.; Parmentier-Batteur, S.; Flick, R. B.; Surles, N. O.; Lam, J. S.; McNaughton, C. H.; Jacobson, M. A.; Hutson, P. H. Dose-dependent effect of CDPPB, the mGluR5 positive allosteric modulator, on recognition memory is associated with GluR1 and CREB phosphorylation in the prefrontal cortex and hippocampus. Neuropharmacology, 2009, 57, 531-538.

[44] Darrah, J. M.; Stefani, M. R.; Moghaddam, B. Interaction of $N$ methyl-D-aspartate and group 5 metabotropic glutamate receptors on behavioral flexibility using a novel operant set-shift paradigm. Behav. Pharmacol., 2008, 19, 225-34.

[45] Balschun, D.; Zuschratter, W.; Wetzel, W. Allosteric enhancement of metabotropic glutamate receptor 5 function promotes spatial memory. Neuroscience, 2006, 142, 691-702.

[46] Ayala, J. E., Chen, Y.; Banko, J. L.; Sheffler, D. J.; Williams, R.; Telk, A. N.; Watson, N. L.; Xiang, Z.; Zhang, Y.; Jones, P. J.; Lindsley, C. W.; Olive, M. F.; Conn, P. J. mGluR5 positive allosteric modulators facilitate both hippocampal LTP and LTD and enhance spatial learning. Neuropsychopharmacology, 2009, 34, 2057-2071.

[47] Lu, Y. M.; Jia, Z.; Janus, C.; Henderson, J. T.; Gerlai, R.; Wojtowicz, J. M.; Roder, J. C. Mice lacking metabotropic glutamate receptor 5 show impaired learning and reduced CA1 long-term potentiation (LTP) but normal CA3 LTP. J. Neurosci., 1997, 17, 5196-5205.

[48] Awad, H.; Hubert, G. W.; Smith, Y.; Levey, A. I.; Conn, P. J. Activation of metabotropic glutamate receptor 5 has direct excitatory effects and potentiates NMDA receptor currents in neurons of the subthalamic nucleus. J. Neurosci., 2000, 20, 78717879 .
[49] Pisani, A.; Gubellini, P.; Bonsi, P.; Conquet, F.; Picconi, B.; Centonze, D.; Bernardi, G.; Calabresi, P. Metabotropic glutamate receptor 5 mediates the potentiation of $N$-methyl-D-aspartate responses in medium spiny striatal neurons. Neuroscience, 2001, 106, 579-587.

[50] O'Brien, J. A.; Lemaire, W.; Wittmann, M.; Jacobson, M. A.; Ha S. N.; Wisnoski, D. D.; Lindsley, C. W.; Schaffhauser, H. J.; Rowe, B.; Sur. C.; Duggan, M. E.; Pettibone, D. J.; Conn, P. J.; Williams, D. L. Jr. A novel selective allosteric modulator potentiates the activity of native metabotropic glutamate receptor subtype 5 in rat forebrain. J. Pharmacol. Exp. Ther., 2004, 309, 568-577.

[51] Lecourtier, L.; Homayoun, H.; Tamagnan, G.; Moghaddam, B. Positive allosteric modulation of metabotropic glutamate 5 (mGlu5) receptors reverses $N$-Methyl-D-aspartate antagonistinduced alteration of neuronal firing in prefrontal cortex. Biol. Psychiatry, 2007, 62, 739-746.

[52] Homayoun, H.; Moghaddam, B. Bursting of prefrontal cortex neurons in awake rats is regulated by metabotropic glutamate 5 (mGlu5) receptors: rate-dependent influence and interaction with NMDA receptors. Cereb. Cortex, 2006, 16, 93-105.

[53] Liu, F.; Zhang, G.; Hornby, G.; Vasylyev, D.; Bowlby, M.; Park, K.; Gilbert, A.; Marquis, K.; Andree, T. H. The effect of mGlu5 receptor positive allosteric modulators on signaling molecules in brain slices. Eur. J. Pharmacol., 2006, 536, 262-268.

[54] Choe, E. S.; Shin, E. H.; Wang, J. Q. Regulation of phosphorylation of NMDA receptor NR1 subunits in the rat neostriatum by group I metabotropic glutamate receptors in vivo. Neurosci. Lett., 2006, 394, 246-251.

[55] Emamian, E. S.; Karayiorgou, M.; Gogos, J. A. Decreased phosphorylation of NMDA receptor type 1 at serine 897 in brains of patients with Schizophrenia. J. Neurosci., 2004, 24, 1561-1564.

[56] Leveque, J. C.; Macías, W.; Rajadhyaksha, A.; Carlson, R. R.; Barczak, A.; Kang, S.; Li, X. M.; Coyle, J. T.; Huganir, R. L.; Heckers, S.; Konradi, C. Intracellular modulation of NMDA receptor function by antipsychotic drugs. J. Neurosci., 2000, 20, 4011-20.

[57] Suzuki, G.; Kimura, T.; Satow, A.; Kaneko, N.; Fukuda, J.; Hikichi, H.; Sakai, N.; Maehara, S.; Kawagoe-Takaki, H.; Hata, M.; Azuma, T.; Ito, S.; Kawamoto, H.; Ohta, H. Pharmacological characterization of a new, orally active and potent allosteric metabotropic glutamate receptor 1 antagonist, 4-[1-(2fluoropyridin-3-yl)-5-methyl-1 $\mathrm{H}$-1,2,3-triazol-4-yl]- $\mathrm{N}$-isopropyl- $\mathrm{N}$ methyl-3,6-dihydropyridine-1(2H)-carboxamide (FTIDC). $J$. Pharmacol. Exp. Ther., 2007, 321, 1144-1153.

[58] Satow, A.; Suzuki, G.; Maehara, S.; Hikichi, H.; Murai, T.; Murai, T.; Kawagoe-Takaki, H.; Hata, M.; Ito, S.; Ozaki, S.; Kawamoto, H.; Ohta, H. Unique antipsychotic activities of the selective metabotropic glutamate receptor 1 allosteric antagonist 2cyclopropyl-5-[1-(2-fluoro-3-pyridinyl)-5-methyl-1 $H$-1,2,3-triazol4-yl]-2,3-dihydro-1H-isoindol-1-one. J. Pharmacol. Exp. Ther., 2009, 330, 179-190.

[59] Satow, A.; Maehara, S.; Ise, S.; Hikichi, H.; Fukushima, M.; Suzuki, G.; Kimura, T.; Tanak, T.; Ito, S.; Kawamoto, H.; Ohta, H. Pharmacological effects of the metabotropic glutamate receptor 1 antagonist compared with those of the metabotropic glutamate receptor 5 antagonist and metabotropic glutamate receptor $2 / 3$ agonist in rodents: detailed investigations with a selective allosteric metabotropic glutamate receptor 1 antagonist, FTIDC [4-[1-(2fluoropyridine-3-yl)-5-methyl-1 $H$-1,2,3-triazol-4-yl]- $N$-isopropyl$\mathrm{N}$-methyl-3,6-dihydropyridine-1(2H)-carboxamide]. J. Pharmacol. Exp. Ther., 2008, 326, 577-586.

[60] Melendez, R. I.; Vuthiganon, J.; Kalivas, P. W. Regulation of extracellular glutamate in the prefrontal cortex: focus on the cystine glutamate exchanger and group I metabotropic glutamate receptors. J. Pharmacol. Exp. Ther., 2005, 314, 139-147.

[61] Kim, J. S.; Schmid-Burgk, W.; Claus, D.; Kornhuber, H. H. Increased serum glutamate in depressed patients. Arch Psychiatr Nervenkr., 1982, 232, 299-304.

[62] Mauri, M. C.; Ferrara, A.; Boscati, L.; Bravin, S.; Zamberlan, F.; Alecci, M.; Invernizzi, G.. Plasma and platelet amino acid concentrations in patients affected by major depression and under fluvoxamine treatment. Neuropsychobiology, 1998, 37, 124-129.

[63] Mitani, H.; Shirayama, Y.; Yamada, T.; Maeda, K.; Ashby, C. R. Jr; Kawahara, R. Correlation between plasma levels of glutamate, 
alanine and serine with severity of depression. Prog. Neuropsychopharmacol. Biol. Psychiatry, 2006, 30, 1155-1158.

[64] Sanacora, G.; Gueorguieva, R.; Epperson, C. N.; Wu, Y. T.; Appel, M.; Rothman, D. L.; Krystal, J. H.; Mason, G. F. Subtype-specific alterations of gamma-aminobutyric acid and glutamate in patients with major depression. Arch. Gen. Psychiatry, 2004, 61, 705-13.

[65] Auer, D. P.; Pütz, B.; Kraft, E.; Lipinski, B.; Schill, J.; Holsboer, F. Reduced glutamate in the anterior cingulate cortex in depression: an in vivo proton magnetic resonance spectroscopy study. Biol. Psychiatry, 2000, 47, 305-313.

[66] Hashimoto, K.; Sawa, A.; Iyo, M. Increased levels of glutamate in brains from patients with mood disorders. Biol. Psychiatry, 2007, 62, 1310-1316.

[67] Murck, H.; Struttmann, T.; Czisch, M.; Wetter, T.; Steiger, A.; Auer, D. P. Increase in amino acids in the pons after sleep deprivation: a pilot study using proton magnetic resonance spectroscopy. Neuropsychobiology, 2002, 45, 120-123.

[68] Pfleiderer, B.; Michael, N.; Erfurth, A.; Ohrmann, P.; Hohmann, U.; Wolgast, M.; Fiebich, M.; Arolt, V.; Heindel, W. Effective electroconvulsive therapy reverses glutamate/glutamine deficit in the left anterior cingulum of unipolar depressed patients. Psychiatry Res., 2003, 122, 185-192.

[69] Choudary, P. V.; Molnar, M.; Evans, S. J.; Tomita, H.; Li, J. Z.; Vawter, M. P.; Myers, R. M.; Bunney, W. E. Jr.; Akil, H.; Watson, S. J.; Jones, E. G. Altered cortical glutamatergic and GABAergic signal transmission with glial involvement in depression. Proc. Natl. Acad. Sci. U. S. A., 2005, 102, 15653-15658.

[70] Nudmamud-Thanoi, S.; Reynolds, G. P. The NR1 subunit of the glutamate/NMDA receptor in the superior temporal cortex in schizophrenia and affective disorders. Neurosci. Lett., 2004, 372, 173-177.

[71] Berman, R. M.; Cappiello, A.; Anand, A.; Oren, D. A.; Heninger, G. R.; Charney, D. S.; Krystal, J. H. Antidepressant effects of ketamine in depressed patients. Biol. Psychiatry, 2000, 47, 351354.

[72] Zarate, C. A. Jr.; Payne, J. L.; Quiroz, J.; Sporn, J.; Denicoff, K. K.; Luckenbaugh, D.; Charney, D. S.; Manji, H. K. An open-label trial of riluzole in patients with treatment-resistant major depression. Am. J. Psychiatry, 2004, 161, 171-174.

[73] Zarate, C. A. Jr.; Singh, J. B.; Carlson, P. J.; Brutsche, N. E.; Ameli, R.; Luckenbaugh, D. A.; Charney, D. S.; Manji, H. K. A randomized trial of an N-methyl-D-aspartate antagonist in treatment-resistant major depression. Arch. Gen. Psychiatry, 2006, 63, 856-64.

[74] Chaki, S.; Yoshikawa, R.; Hirota, S.; Shimazaki, T.; Maeda, M.; Kawashima, N.; Yoshimizu, T.; Yasuhara, A.; Sakagami, K.; Okuyama, S.; Nakanishi, S.; Nakazato, A. MGS0039: a potent and selective group II metabotropic glutamate receptor antagonist with antidepressant-like activity. Neuropharmacology, 2004, 46, 457-467.

[75] Witkin, J. M.; Marek, G. J.; Johnson, B. G.; Schoepp, D. D. Metabotropic glutamate receptors in the control of mood disorders. CNS Neurol. Disord. Drug Targets, 2007, 6, 87-100.

[76] Morishima, Y.; Miyakawa, T.; Furuyashiki, T.; Tanaka, Y.; Mizuma, H.; Nakanishi, S. Enhanced cocaine responsiveness and impaired motor coordination in metabotropic glutamate receptor sub/type 2 knockout mice. Proc. Natl. Acad. Sci. USA, 2005, 102, 4170-4175.

[77] Kenny, P. J.; Gasparini, F.; Markou, A. Group II metabotropic and alpha-amino-3-hydroxy-5-methyl-4-isoxazole propionate (AMPA)/kainate glutamate receptors regulate the deficit in brain reward function associated with nicotine withdrawal in rats. J. Pharmacol. Exp. Ther., 2003, 306, 1068-1076.

[78] Barr, A. M.; Markou, A.; Phillips, A. G. A 'crash' course on psychostimulant withdrawal as a model of depression. Trends Pharmacol. Sci., 2002, 23, 475-482.

[79] Yoshimizu, T.; Shimazaki, T.; Ito, A.; Chaki, S. An mGluR2/3 antagonist, MGS0039, exerts antidepressant and anxiolytic effects in behavioral models in rats. Psychopharmacology (Berl), 2006, 186, 587-593.

[80] Kawashima, N.; Karasawa, J.; Shimazaki, T.; Chaki, S.; Okuyama, S.; Yasuhara, A.; Nakazato, A. Neuropharmacological profiles of antagonists of group II metabotropic glutamate receptors. Neurosci. Lett., 2005, 378, 131-4.
[81] Karasawa, J.; Yoshimizu, T.; Chaki, S. A metabotropic glutamate $2 / 3$ receptor antagonist, MGS0039, increases extracellular dopamine levels in the nucleus accumbens shell. Neurosci. Lett., 2006, 393, 127-130.

[82] Yoshimizu, T.; Chaki, S. Increased cell proliferation in the adult mouse hippocampus following chronic administration of group II metabotropic glutamate receptor antagonist, MGS0039. Biochem. Biophys. Res. Commun., 2004, 315, 493-496.

[83] Karasawa, J.; Shimazaki, T.; Kawashima, N.; Chaki, S. AMPA receptor stimulation mediates the antidepressant-like effect of a group II metabotropic glutamate receptor antagonist. Brain Res., 2005, 1042, 92-98.

[84] Shimazaki, T.; Kaku, A.; Chaki, S. Blockade of the metabotropic glutamate $2 / 3$ receptors enhances social memory via the AMPA receptor in rats. Eur. J. Pharmacol., 2007, 575, 94-97.

[85] Alt, A.; Nisenbaum, E. S.; Bleakman, D.; Witkin, J. M. A role for AMPA receptors in mood disorders. Biochem. Pharmacol., 2006, 71, 1273-1288.

[86] Du, J.; Suzuki, K.; Wei, Y.; Wang, Y.; Blumenthal, R.; Chen, Z.; Falke, C.; Zarate, C. A. Jr.; Manji, H. K. The anticonvulsants lamotrigine, riluzole, and valproate differentially regulate AMPA receptor membrane localization: relationship to clinical effects in mood disorders. Neuropsychopharmacology, 2007, 32, 793-802.

[87] Maeng S.; Zarate C. A. Jr.; Du J.; Schloesser R. J.; McCammon, J.; Chen, G.; Manji, H. K., Cellular mechanisms underlying the antidepressant effects of ketamine: role of alpha-amino-3-hydroxy5-methylisoxazole-4-propionic acid receptors. Biol. Psychiatry, 2008, 63, 349-52.

[88] Li, X.; Need, A. B.; Baez, M.; Witkin, J. M. Metabotropic glutamate 5 receptor antagonism is associated with antidepressantlike effects in mice. J. Pharmacol. Exp. Ther., 2006, 319, 254-259.

[89] Pałucha, A.; Brański, P.; Szewczyk, B.; Wierońska, J. M.; Kłak, K.; Pilc, A. Potential antidepressant-like effect of MTEP, a potent and highly selective mGluR5 antagonist. Pharmacol. Biochem. Behav., 2005, 81, 901-906.

[90] Tatarczyńska E, Klodzińska A, Chojnacka-Wójcik E, Palucha A, Gasparini F, Kuhn R, Pilc A. Potential anxiolytic- and antidepressant-like effects of MPEP, a potent, selective and systemically active mGlu5 receptor antagonist. Br. J. Pharmacol., 2001, 132(7), 1423-30.

[91] Pilc, A.; Kłodzińska, A.; Brański, P.; Nowak, G.; Pałucha, A.; Szewczyk, B.; Tatarczyńska, E.; Chojnacka-Wójcik, E.; Wierońska, J. M. Multiple MPEP administrations evoke anxiolytic- and antidepressant-like effects in rats. Neuropharmacology, 2002, 43, 181-187.

[92] Molina-Hernández, M.; Tellez-Alcántara, N. P.; Pérez-García, J.; Olivera-Lopez. J. I.; Jaramillo, M. T. Antidepressant-like and anxiolytic-like actions of the mGlu5 receptor antagonist MTEP, microinjected into lateral septal nuclei of male Wistar rats. Prog. Neuropsychopharmacol. Biol. Psychiatry, 2006, 30, 1129-1135.

[93] D'Ascenzo, M.; Fellin, T.; Terunuma, M.; Revilla-Sanchez, R.; Meaney, D. F.; Auberson, Y. P.; Moss, S. J.; Haydon, P. G.. mGluR5 stimulates gliotransmission in the nucleus accumbens. Proc. Natl. Acad. Sci. USA, 2007, 104, 1995-2000.

[94] Cryan, J. F.; Kelly, P. H.; Neijt, H. C.; Sansig, G.; Flor, P. J.; van Der Putten, H. Antidepressant and anxiolytic-like effects in mice lacking the group III metabotropic glutamate receptor mGluR7. Eur. J. Neurosci., 2003, 17, 2409-2417.

[95] Mitsukawa, K.; Mombereau, C.; Lötscher, E.; Uzunov, D. P.; van der Putten, H.; Flor, P. J.; Cryan, J. F. Metabotropic glutamate receptor subtype 7 ablation causes dysregulation of the HPA axis and increases hippocampal BDNF protein levels: implications for stress-related psychiatric disorders. Neuropsychopharmacology, 2006, 31, 1112-1122.

[96] Holsboer, F.; Bender, W.; Benkert, O.; Klein, H. E.; Schmauss, M. Diagnostic value of dexamethasone suppression test in depression. Lancet, 1980, 2, 706.

[97] Palucha, A.; Klak, K.; Branski, P.; van der Putten, H.; Flor, P. J.; Pilc, A. Activation of the $\mathrm{mGlu} 7$ receptor elicits antidepressant-like effects in mice. Psychopharmacology (Berl), 2007, 194, 555-562.

[98] Pelkey, K. A.; Yuan, X.; Lavezzari, G.; Roche, K. W.; McBain, C. J. mGluR7 undergoes rapid internalization in response to activation by the allosteric agonist AMN082. Neuropharmacology, 2007, 52, 108-117. 
[99] Nakagawa, Y.; Saitoh, K.; Ishihara, T.; Ishida, M.; Shinozaki, H. $(2 S, 3 S, 4 S) \alpha$-(Carboxycyclopropyl)glycine is a novel agonist of metabotropic glutamate receptors. Eur. J. Pharmacol., 1990, 184, 205-206.

[100] Ohfune, Y.; Shimamoto, K.; Ishida, M.; Shinozaki, H. Synthesis of L-2-(2,3-dicarboxyclopropyl)glycines. Novel conformationally restricted glutamate analogues. Bioorg. Med. Chem. Lett., 1993, 3, $15-18$.

[101] Brabet, I.; Parmetier, M.-L.; Colle, C. D.; Bockaert, J.; Acher, F.; Pin, J. -P. Comparative effect of 1-CCG-I, DCG-IV and $\gamma$-carboxyL-glutamate on all cloned metabotropic glutamate receptor subtypes. Neuropharmacology, 1998, 37, 1043-1051.

[102] Monn, J. A.; Valli, M. J.; Massey, S. M.; Wright, R. A.; Salhoff, W. C.; Johnson, B. G.; Howe, T.; Alt, C. A.; Rhodes, G. A.; Robey, R. L.; Griffey, K. R.; Tizzano, J. P.; Kallman, M. J.; Helton, D. R.; Schoepp, D. D. Design, synthesis, and pharmacological characterization of (+)-2-aminobicyclo[3.1.0]hexane-2,6-dicarboxyloc acid (LY354740): a potent, selective, and orally active group 2 metabotropic glutamate receptor agonist possessing anticonvulsant and anxiolytic properties. J. Med. Chem., 1997, 40, 528-537.

[103] Monn. J. A.; Valli, M. J.; Massey, S. M.; Hansen, M. M.; Kress, T. J.; Wepsiec, J. P.; Harkness, A. R.; Grutsch, J. L.; Wright, R. A., Johnson, B. G.; Andis, S. L.; Kingston, A.; Tomlinson, R.; Lewis, R.; Griffey, K. R.; Tazzano, J. P.; Schoepp, D. D. Synthesis, pharmacological characterization, and molecular modering of heterobicyclic amino acids related to (+)-2-aminobicyclo[3.1.0]hexane-2,6-dicarboxylic acid (LY354740): identification of two new potent, selective, and systemically active agonists for group II metabotropic glutamate receptors. J. Med. Chem., 1999, 42, 1027-1040.

[104] Johnson, M. P.; Baez, M.; Jagdmann, Jr. G. E.; Britton, T. C.; Large, T. H.; Callagaro, D. O.; Tizzano, J. P.; Monn, J. A.; Schoepp, D. D. Discovery of allosteric potentiators for the metabotropic glutamate 2 receptor: synthesis and subtype selectivity of $N$-(4-(2-methoxyphenoxy)phenyl)-N-(2,2,2-trifluoroethylsulfonyl)pyrid-3-ylmethylamine. J. Med. Chem., 2003, 46, 3189-3192.

[105] Johnson, M. P.; Barda, D,; Britton, T. C.; Emkey, R.; Hornback, W. J.; Jagdmann, G. E.; McKinzie, D. L.; Nisenbaum, E. S.; Tizzano, J. P.; Schoepp, D. D. Metabotropic glutamate 2 receptor potentiators: receptor modulation, frequency-dependent synaptic activity, and efficacy in preclinical anxiety and psychosis model(s). Psychopharmacology, 2005, 179, 271-283.

[106] Pinkerton, A. B.; Vernier, J.-M.; Schaffhauser, H.; Rowe, B. A.; Campbell, U. C.; Rodriguez, D. E.; Lorrain, D. S.; Baccei, C. S.; Daggett, L. P.; Bristow, L. J. Phenyl-tetrazolyl acetophenones: discovery of positive allosteric potentiatiors for the metabotropic glutamate 2 receptor. J. Med. Chem., 2004, 47, 4595-4599.

[107] Pinkerton, A. B.; Cube, R. V.; Hutchinson, J. H.; Rowe, B. A.; Schaffhauser, H.; Zhao, X.; Daggett, L. P.; Vernier, J.-M. Allosteric potentiators of the metabotropic glutamate receptor 2 (mGlu2). Part 1: Identification and synthesis of phenyl-tetrazolyl acetophenones. Bioorg. Med. Chem. Lett., 2004, 14, 5329-5332.

[108] Arnold, M. B.; Bleisch, T. J.; Helton, D. E.; Kallman, M. J.; Ornstein, P. L.; Schoepp, D. D.; Tizzano, J. P. Excitatory amino acid receptor antagonists. WO199607405 (1996).

[109] Kingston, A. E.; Ornstein, P. L.; Wright, R. A.; Johnson, B. G.; Mayne, N. G.; Burnett, J.P.; Belagaje, R.; Wu, S.; Schoepp, D. D. LY341495 is a nanomolar potent and selective antagonist of group II metabotropic glutamate receptors. Neuropharmacology, 1998, $37,1-12$.

[110] Ornstein, P. L.; Bleisch, T. J.; Arnold, M. B.; Kennedy, J. H.; Wright, R. A.; Johnson, B. G.; Tizzano, J. P.; Helton, D. R.; Kallman, M. J.; Schoepp, D. D. 2-substituted (2SR)-2-amino-2$((1 S R, 2 S R)$-2-carboxycycloprop-1-yl)glycines as potent and selective antagonists of group II metabotropic glutamate receptors. 2. Effects of aromatic substitution, pharmacological characterization, and bioavailability. J. Med. Chem., 1998, 41, 358-378.

[111] Nakazato, A.; Sakagami, K.; Yasuhara, A.; Ohta, H.; Yoshikawa, R.; Itoh, M.; Nakamura, M.; Chaki, S. Synthesis, in vitro pharmacology, structure-activity relationships, and pharmacokinetics of 3-alkoxy-2-amino-6-fluorobicyclo[3.1.0]hexane-2,6-dicarboxylic acid derivatives as potent and selective group
II metabotropic glutamate receptor antagonists. J. Med. Chem., 2004, 47, 4570-4587.

[112] Yasuhara, A.; Nakamura, M.; Sakagami, K.; Shimazaki, T.; Yoshikawa, R.; Chaki, S.; Ohta, H.; Nakazato, A. Prodrugs of 3(3,4-dichlorobenzyloxy)-2-amino-6-fluorobicyclo[3.1.0]hexane2,6-dicarboxylic acid (MGS0039): a potent and orally active group II mGluR antagonist with antidepressant-like potential. Bioorg. Med. Chem., 2006, 14, 4193-4207.

[113] Adam, G.; Kolczewski, S.; Mutel, V.; Standler, H.; Wichmann, J. Woltering, T. J. Heterocyclic vinylethers against neurological disorders. WO199902678 (1999).

[114] Adam, G.; Goetschi, E.; Wichmann, J.; Woltering, T. J. Dihydrobenzodiazepin-2-one derivatives for the treatment of neurological disorders. WO2003066623 (2003).

[115] Adam, G.; Kolczewski, S.; Mutel, V.; Wichmann, J.; Woltering, T. J. 5 H-Thiazolo(3,2- $\alpha)$ pyrimideine derivatives. EP0891978 (2002).

[116] Goetschi, E.; Wichmann, J.; Woltering, T. J. Pyrrazolo-pyrimidine derivatives. WO2005123738 (2005).

[117] Wichmann, J.; Woltering, T. J. Pyrazolo and imidazo-pyrimidine derivatives. WO2005040171 (2005).

[118] Gatti McArthur, S.; Goetschi, E.; Wichmann, J.; Woltering, T. J. Pyrazolo-pyrimideine derivatives as mGluR2 antagonists. WO2006084634 (2006).

[119] Gatti McArthur, S.; Goetschi, E.; Palmer, W. S.; Wichmann, J.; Woltering, T. J. Acetylenyl-pyrazolo-primideine derivatives as mGluR2 antagonists. WO2006099972 (2006).

[120] Gatti McArthur, S.; Goetschi, E.; Wichmann, J. Imidazole derivatives. US20060173048 (2006).

[121] Kingston, A. E.; Burnett, J. P.; Mayne, N. G.; Lodge, D. Pharmacological analysis of 4-carboxyphenylglycine derivatives: Comparison of effects on mGluR $1 \alpha$ and mGluR5a subtypes. Neuropharmacology, 1995, 34, 887-894.

[122] Clark, B. P.; Baker, S. R.; Goldsworthy, J.; Harris, J. R.; Kingston, A. E. (+)-2-Methyl-4-carboxyphenylglycine (LY367385) selectively antagonises metabotropic glutamate mGluR1 receptors. Bioorg. Med. Chem. Lett., 1997, 7, 2777-27800.

[123] Pellicciari, R.; Luneia, R.; Costantino, G.; Marinozzi, M.; Natalini, B.; Jakobsen, P.; Kanstrup, A.; Lombardi, G.; Moroni, F.; Thomsen, C. 1-Aminoindan-1,5-dicarboxylic acid: A novel antagonist at phospholipase C-linked metabotropic glutamate receptors, J. Med. Chem., 1995, 38, 3717.

[124] Moroni, F.; Lombardi, G.; Thomsen, C.; Leonardi, P.; Attucci, S.; Peruginelli, F.; Torregrossa, S. A.; Pellegrini-Giampetro, D.E.; Luneia, R.; Pellicciari, R. Pharmacological characterization of 1aminoindan-1,5-dicarboxylic acid, a potent mGluR1 antagonist. $J$. Pharmcol. Exp. Ther., 1997, 281, 721.

[125] Pellicciari, R.; Raimondo, M.; Marinozzi, M.; Natalini, B.; Costantino, B.; Thomsen, C. $(S)-(+)-2-\left(3^{\circ}\right.$-Carboxybicyclo[1.1.1]pentyl)- glycine, a structurally new group I metabotropic glutamate receptor antagonist. J. Med. Chem., 1996, 39, 2874.

[126] Pellicciari, R.; Costantino, G.; Giovagnoni, E.; Mattoli, L.; Brabet,I; Pin, J-. P. Synthesis and preliminary evaluation of $(S)-2-$ (4'-carboxycubyl)glycine, a new selective mGluR1 antagonist, Bioorg. Med. Chem. Lett., 1998, 8, 1569.

[127] Schoepp, D. D.; Jane, D. E.; Monn, J. A. Pharmacological agents acting at subtypes of metabotropic glutamate receptors. Neuropharmacology, 1999, 38, 1431.

[128] Gasparini, F.; Kuhn, R.; Pin, J-. P. Allosteric modulators of group I metabotropic glutamate receptors: novel subtype-selective ligands and therapeutic perspectives. Curr. Opin. Pharmacol., 2002, 2, 43.

[129] Annoura, H.; Fukunaga, A.; Uesugi, M.; Tatsuoka, T.; Horikawa, Y. A novel class of antagonists for metabotropic glutamate receptors, 7-(Hydroxyimino)cyclopropa[b]chromen-1a-carboxylates. Bioorg. Med. Chem. Lett., 1996, 6, 763.

[130] Litschig, S.; Gasparini, F.; Rueegg, D.; Stoehr, N.; Flor, P. J.; Vranesic, I.; Prezeau, L.; Pin, J-. P.; Thomsen, C.; Kuhn, R. CPCCOEt, a noncompetitive metabotropic glutamate receptor 1 antagonist, inhibits receptor signaling without affecting glutamate binding. Mol. Pharmcol., 1999, 55, 453.

[131] Ott, D.; Floersheim, P.; Inderbitzin, W.; Stoehr, N.; Francotte, E.; Lecis, G.; Richert, P.; Rihs, G.; Flor, P. J.; Rainer Kuhn, R.; Gasparini, F. Chiral resolution, pharmacological characterization, and receptor docking of the noncompetitive mGlu1 receptor antagonist (+/-)-2-hydroxyimino- 1a, 2-dihydro-1 $\mathrm{H}$-7-oxacyclo- 
propa[b]naphthalene-7a-carboxylic acid ethyl ester. J. Med. Chem., 2000, 43, 4428 .

[132] Carroll, F. Y.; Stolle, A.; Beart, P. M.; Voerste, A.; Brabet, I.; Mauler, F.; Joly, C.; Antonicek, H.; Bockaert, J.; Müller, T.; Pin, J. P.; Prézeau, L. BAY36-7620: a potent non-competitive mGlu1 receptor antagonist with inverse agonist activity. Mol. Pharmcol., 2001, 59, 965

[133] Lundbeck, J. M. Heterocyclic compounds, their preparation and use. WO199705109 (1997).

[134] Olesen, P. H. Heterocyclic compounds, their preparation and use. WO199705137 (1997).

[135] Hayashibe, S.; Itahana, H.; Okada, M.; Kohara, A.; Maeno, K.; Yahiro, K.; Shimada, I.; Tanabe, K.; Negoro, K.; Kamikubo, T.; Sakamoto, S. Novel thiazolobenzimidazole derivatives. WO200059913 (2000).

[136] Itahana, H.; Fujiyasu, J.; Hayashibe, S.; Watanabe, T.; Okada, M.; Toya, T. Aminomethyl-substitutes thiazolobenzimidazole derivatives. WO2003078441 (2003).

[137] Itahana, H.; Fujiyasu, J.; Watanabe, T.; Okada, M.; Toya, T. Aminomethyl-substituted fluorothiazolobenzimidazole derivative. WO2004/106348 (2004).

[138] Kohara, A.; Toya, T.; Tamura, S.; Watabiki, T.; Nagakura, Y.; Shitaka, Y.; Hayashibe, S.; Kawabata, S.; Okada, M. Radioligand binding properties and pharmacological characterization of 6amino- $N$-cyclohexyl- $N, 3$-dimethylthiazolo[3,2-a]benzimidazole-2carboxamide (YM-298198), a high-affinity, selective, and noncompetitive antagonist of metabotropic glutamate receptor type 1. J. Pharmcol. Exp. Ther., 2005, 315, 163.

[139] Matasi, J.; Tulshian, D.; Burnett, D. A.; Wu, W-. L.; Korakas, P.; Silverman, L.S.; Sasikumar, T. K.; Qiang, L. Momalski, M. S. Tricyclic compounds and their use as mGluR1 antagonists. WO2006002051 (2006).

[140] Mabire, D. J-. P.; Venet, M. G.; Coupa, S. Poncelet, A. P.; Lesage, A. S. J. Metabotropic glutamate receptor antagonists. WO200228837 (2002).

[141] van Wargene, B. C.; Moe, S. T.; Smith, D. L.; Sheehan, S. M.; Shcherbakova, I.; Travato, R.; Walton, R.; Barmore, R.; Delmar, E. G.; Stormann, T. M. Metabotropic glutamate receptor antagonists and their use for treating central nervous system diseases.WO200073283 (2000).

[142] Adam, G.; Binggeli, Alfred.; Maerki, H-. P.; Mutel, V.; Wilhelm, M.; Wostl. W. Tetrahydro-benzo(d)azepines and their use as antagonists at metabotropic glutamate. EP1 074549 (2003).

[143] Binggel, A.; Maerki, H-. P.; Mutel, V.; Wilhelm, M.; Wostl, W. Tetrahydro-(benzo or thieno)-azepine-pyrazine and triazine derivatives as mGluR 1 antagonists. WO2002051418 (2002).

[144] Binggel, A.; Maerki, H-. P.; Masquelin, T.; Mutel, V.; Wilhelm, M.; Wostl, W. Pyrimidine, triazine and pyrazine derivatives as glutamate receptors. WO2002098864 (2002).

[145] Satoh, A.; Kawamoto, H.; Kimura, T.; Suzuki, G.; Sato, A.; Ohta, H. 1,4-Substituted piperazine derivatives. WO2006109817 (2006).

[146] Kawamoto, H.; Ito, S.; Satoh, A.; Nagatomi, Y.; Hirata, Y.; Kimura, T.; Suzuki, G.; Sato, A.; Ohta, H. Oxopiperazine derivative. WO2006006610 (2006).

[147] Kawamoto, H.; Ito, S.; Satoh, A.; Nagatomi, Y.; Hirata, Y.; Kimura, T.; Suzuki, G.; Sato, A.; Ohta, H. Diaryl-substituted fivemembered heterocycle derivative. WO2005085214 (2005).

[148] Parsons, C.; Graham, R.; Jirgensons, A.; Jauzeme, I.; Kalvinsh, I.; Henrich, M.; Vanejevs, M.; Weil, T.; Kauss, V.; Danysz, W. Tetrahydroquinolinones and their use as antagonists of metabotropic glutamate receptors. WO2005082856 (2009).

[149] Schoepp, D. D.; Goldsworthy, J.; Johnson, B. G.; Salhoff, C. R.; Baker, S. R. 3,5-Dihydroxyphenylglycine is a highly selective agonist for phosphoinositide-linked metabotropic glutamate receptors in the rat hippocampus. J. Neurochem., 1994, 63, 769772 .

[150] Baker, S. R.; Goldsworthy, J.; Harden, R. C.; Salhoff, C. R.; Schoepp, D. D. Enzymatic resolution and pharmacological activity of the enantiomers of 3,5-dihydroxyphenylglycine, a metabotropic glutamate receptor agonist. Bioorg. Med. Chem. Lett., 1995, 5, 223228 .

[151] Littman, L.; Tokar, C.; Venkatraman, S.; Roon, R. J.; Koerner, J. F.; Robinson, M. B.; Jonson, R. L. Cyclobutane quisqualic acid analogues as selective mGluR5a metabotropic glutamic acid receptor ligands. J. Med. Chem., 1999, 42, 1639-1647.

[152] O’Brien, J. A.; Lemaire, W.; Wittmann, M.; Jacobson, M. A.; Ha, S. N.; Wisnoski, D. D.; Lindsley, C. W.; Schaffhauser, H. J.; Rowe, B.; Sur, C.; Duggan, M. E.; Pettibone, D. J.; Conn, P. J.; Williams, Jr. D. L. A novel selective allosteric modulator potentiates the activity of native metabotropic glutamate receptor subtype 5 in rat forebrain. J. Pharmcol. Exp. Ther., 2005, 47, 5825-5828.

[153] O'Brien, J. A.; Lemaire, W.; Chen, T.-B.; Chang, R. S. L.; Jacobson, M. A.; Ha, S. N.; Lindsley, C. W.; Schaffhauser, H. J.; Sur, C.; Pettibone, D. J.; Conn, P. J.; Williams, Jr. D. L. A family of highly selective allosteric modulators of the metabotropic glutamate receptor subtype 5. Mol. Pharmacol. 2003, 64, 731-740.

[154] Chen, Y.; Nong, Y.; Goudet, C.; Hemstapat, K.; de Paulis, T.; Pin, J.-P.; Conn P. J. Interaction of novel positive allosteric modulators of metabotropic glutamate receptor 5 with the negative allosteric antagonist site is required for potentiation of receptor responses, Mol. Pharmacol., 2007, 71, 1389-1398.

[155] Lindsley, C. W.; Wisnoski, D. D.; Leister, W. H.; O'Brien, J. A.; Lemaire, W.; Williams, Jr., D. L.; Burno, M.; Sur, C.; Kinney, G. G..; Pettibone, D. J.; Tiller, P. R.; Smith, S.; Duggan, M. E.; Hartman, G. D.; Conn, P. J.; Huff, J. R. Discovery of positive allosteric modulators for the metabotropic glutamate receptor subtype 5 from a series of $N$-(1,3-diphenyl- $1 H$ - pyrazol-5yl)benzamides that potentiate receptor function in vivo. J. Med. Chem., 2004, 47, 5825-5828.

[156] Bessis A.S.; Bonnet, B.; Poul E.; Rocher J.P.; Epping-Jordan, M.P. Allosteric modulators of metabotropic glutamate receptors. WO2005044797 (2005)

[157] Epping-Jordan, M.P.; Nayak, S.; Derouet, F.; Dominguez, H.; Bessis A. S.; Le Poul E.; Ludwig B. L.; Mutel V.; Poli S. M.; Rocher J. P. In vivo characterization of mGluR5 positive allosteric modulators as novel treatments for schizophrenia and cognitive dysfunction. Neuropharmacology, 2005, 49, 231-279. Abstr.42.

[158] A. Varney, M. A.; Cosford, N. D. P; Jachec, C.; Rao, S. P.; Sacaan, A.; Lin, F-. F.; Bleicher, L.; Santori, E. M.; Flor, P. J.; Allgeier, H.; FABRIZIO Gasparini, F.; Kuhn, P.; Hess, S. D.; Veliçelebi, G.; Johnson, E. C. SIB-1757 and SIB-1893: selective, noncompetitive antagonists of metabotropic glutamate receptor type $5 . J$. Pharmcol. Exp. Ther., 1999, 290, 170-181.

[159] Gasparini, F.; Lingenhöhl, K.; Stoehr, N.; Flor, P. J.; Heinrich, M.; Vranesic, I.; Biollaz, M.; Allgeier, H.; Heckendorn, R.; Urwyler, S.; Varney, M. A.; Johnson, E. C.; Hess, S. D.; Rao, S. P.; Sacaan, A. I.; Santori, E. M., Veliçelebi, G.; Kuhn, R. 2-Methyl-6-(phenylethynyl)-pyridine (MPEP), a potent, selective and systemically active mGlu5 receptor antagonist. Neuropharmacology, 1999, 38, 1493-1503.

[160] Cosford, N. D. P.; Tehrani, L.; Roppe, J.; Schweiger, E.; Smith, N. D.; Anderson, J.; Bristow, L.; Brodkin, J.; Jiang, X.; McDonald, I.; Rao, S.; Washburn, M.; Varney, M. A. 3-[(2-Methyl-1,3-thiazol-4yl)ethynyl]-pyridine: a potent and highly selective metabotropic glutamate subtype 5 receptor antagonist with anxiolytic activity. $J$. Med. Chem., 2003, 46, 204-206.

[161] Gasparini, F.; Andres, H.; Flor, P. J.; Heinrich, M.; Inderbitzin, W.; Lingenhöhl, K.; Müller, H.; Munk, V. C.; Omilusik, K.; Stierlin, C.; Stoehr, N.; Vranesic, I.; Kuhn, R. [(3)H]-M-MPEP, a potent, subtype-selective radioligand for the metabotropic glutamate receptor subtype 5. Bioorg. Med. Chem. Lett., 2002, 12, 407-409.

[162] Cosford, N. D. P.; Jeffrey Roppe, J.; Tehrani, L.; Schweiger, E. J.; Seiders, T. J.; Chaudary, A.; Rao, S.; Varney, M. A. [3H]methoxymethyl-MTEP and [3H]-methoxy-PEPy: potent and selective radioligands for the metabotropic glutamate subtype 5 (mGlu5) receptor. Bioorg. Med. Chem. Lett., 2003, 13, 351-354.

[163] Anderson, J. J.; Rao, S. P.; Rowe, B.; Giracello, D. R.; Holtz, G.; Chapman, D. F.; Tehrani, L.; Bradbury, M. J.; Cosford, N. D. P.; Varney, M. A. 3H]Methoxymethyl-3-[(2-methyl-1,3-thiazol-4yl)ethynyl]pyridine binding to metabotropic glutamate receptor subtype 5 in rodent brain: in vitro and in vivo characterization. $J$. Pharmcol. Exp. Ther., 2002, 303, 1044-1051.

[164] Roppe, J. R.; Wang, B.; Huang, D.; Tehrani, L.; Kamenecka, T.; Schweiger, E. J.; Anderson, J. J.; Brodkin, J.; Jiang, X.; Cramer, M.; Chung, J.; Manalo, G. R-.; Munoza, B.; Cosford, N. D. P. 5 [(2-Methyl-1,3-thiazol-4-yl)ethynyl]-2,3'-bipyridine: a highly potent, orally active metabotropic glutamate subtype 5 (mGlu5) 
receptor antagonist with anxiolytic activity. Bioorg. Med. Chem. Lett., 2004, 14, 3993-3996.

[165] Alagille, D.; Baldwin, R. M.; Roth, B. L.; Wroblewski, J. T.; Grajkowskac, E.; Tamagnan, G. D. Functionalization at position 3 of the phenyl ring of the potent mGluR5 noncompetitive antagonists MPEP. Bioorg. Med. Chem., 2005, 15, 945-949.

[166] Bach, P.; Nilsson, K.; Wa ${ }^{\circ}$ llberg, A.; Bauer, U.; Hammerland, L. G.; Peterson, A.; Svensson, T.; Österlund, K.; Karis, D.; Boijea, M.; Wensboc, D. A new series of pyridinyl-alkynes as antagonists of the metabotropic glutamate receptor 5 (mGluR5). Bioorg. Med. Chem., 2006, 16, 4792-4795.

[167] Glatthar, R.; Troxler, T. J.; Zoller, T.; Nozulak, J. Pyrrolidine and piperidine acetylene derivatives for use as mGluR5 antagonists. WO2006089700 (2006).

[168] Wang, B.; Varney, M. A.; Rao, S.; Chung, J.; Anderson, J. J.; Brodkin, J. D.; Jiang, X; Gardner, M. F.; Yanga, X.; Munoz, B. Discovery of novel modulators of metabotropic glutamate receptor subtype-5. Bioorg. Med. Chem., 2004, 12, 17-21.

[169] van Wagenen, B.; Stormann, T. M.; Moe, S. T.; Sheehan, S. M.; Mcleod, D. A.; Smith, D. L.; Isaac, M. B. Heteropolycyclic compounds and their use as metabotropic glutamate receptor antagonists. WO2002068417 (2002).

[170] Roppe, J.; Smith, N. D.; Huang, D.; Tehrani, L.; Wang, B.; Anderson, J.; Brodkin, J.; Chung, J.; Jiang, X; King, C.; Munoz, B.; Varney, M. A.; Prasit, P.; Cosford, N. D. P. Discovery of novel heteroarylazoles that are metabotropic glutamate subtype 5 receptor antagonists with anxiolytic activity. J. Med. Chem., 2004, 47, 46454648 .

[171] Mitsukawa, K.; Yamamoto, R.; Ofner, S.; Nozulak, J.; Pescott, O., Lukic, S.; Stoehr, N.; Mombereau, C.; Kuhn, R.; McAllister, K.h.; van der Putten, H.; Cryan, J. F.; Flor, P. J. A selective metabotropic glutamate receptor 7 agonist: activation of receptor signaling via an allosteric site modulates stress parameters in vivo. Proc. Natl. Acad. Sci. USA, 2005, 102, 18712-18717.

[172] Conn, P. J.; Niswener, C. M. mGlur7's lucky number. Proc. Natl. Acad. Sci. USA, 2006, 103, 251-252.

[173] Suzuki, G.; Tsukamot, N.; Fushiki, H.; Kawagishi, A.; Nakamura, M.; Kurihara, H.; Mitsuya, M.; Ohkubo, M.; Ohta, H. In vitro pharmacological characterization of novel isoxazolopyridone derivatives as allosteric metabotropic glutamate receptor 7 antagonists. J. Pharmcol. Exp. Ther., 2007, 323, 147-156. 